THE DEBT COUNSELLING PROCESS - CLOSING THE LOOPHOLES IN THE NATIONAL CREDIT ACT 34 OF 2005

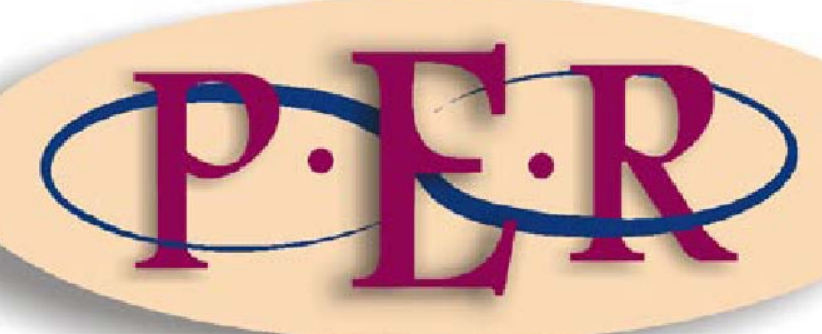

2009 VOLUME 12 No 4 


\title{
THE DEBT COUNSELLING PROCESS - CLOSING THE LOOPHOLES IN THE NATIONAL CREDIT ACT 34 OF $2005^{1}$
}

\author{
M Roestoff, ${ }^{*}$ F Haupt, ${ }^{* *}$ H Coetzee ${ }^{* \star *}$ and M Erasmus ${ }^{* \star *}$
}

\section{Introduction}

According to statistics provided by the National Credit Regulator (NCR) $41.6 \%$ of the 17.57 million credit-active South Africans had impaired credit records in December $2008 .^{2}$ This "impaired records" ${ }^{3}$ figure rose by $4 \%$ when compared to the quarter which ended in December 2007. Since December 2008 the number of consumers with impaired credit records has further increased. As at March 2009 credit bureaux had records for 17.61 million credit-active consumers. The data showed that the percentage of consumers with impaired records was $42.4 \%$ at the quarter ending March 2009. This was an increase of $0.8 \%$ when compared with the quarter ending December 2008 and an increase of $4 \%$ when compared with the quarter ending March $2008 .^{4}$

Further statistics ${ }^{5}$ show that in December 2008, just over 42000 consumers have applied for debt review in terms of section 86 of the National Credit Act (NCA), ${ }^{6}$ however, less than 1600 cases have managed to proceed through our courts. These statistics indicate that the debt counselling process is not

* $\quad$ Melanie Roestoff. BLC LLB LLM LLD, Professor, University of Pretoria

** Franciscus Haupt. BA LLB, Director, Law Clinic, University of Pretoria.

*** Hermie Coetzee. B Com (Law) LLB, Lecturer, University of Pretoria.

**** Mareesa Erasmus. LLB, Attorney, Law Clinic, University of Pretoria.

1 This article is based on ch 2 of a research report submitted by the University of Pretoria Law Clinic to the National Credit Regulator. See Haupt, Roestoff and Erasmus Debt Counselling Process.

2 CBM 2008 www.ncr.org.za

3 According to the NCR, consumers have impaired credit records "if any of their accounts is classified as 3 or more payments in arrears, or has an 'adverse listing', or consumers have a judgment or an administration order against their names" CBM 2008 www.ncr.org.za

4 CBM 2009 www.ncr.org.za

5 Provided by the NCR.

6 Act 35 of 2005 - hereafter the NCA. 
functioning effectively, thereby denying many consumers the protective measures afforded by the Act.

In January 2009, the NCR and Business Enterprises at the University of Pretoria entered into an agreement in terms of which the Law Clinic of the University of Pretoria in collaboration with the University's Bureau for Statistical and Survey Methodology were to conduct an assessment of the reasons for the ineffectiveness of the debt counselling process. The research was done during the period of January to April 2009 and was reported on in a document entitled The Debt Counselling Process: Challenges to Consumers and the Credit Industry in General. ${ }^{7}$

It should be clear that the success of debt counselling and the debt review process depends on a positive working relationship between the over-indebted consumer, credit providers and debt counsellors who must act as intermediaries and aim to strike a balance between the different role players' conflicting needs and interests. ${ }^{8}$ This challenge has been explained as follows:

On the one side is a consumer who is over-indebted but does not want to accept that he is living beyond his means and will have to reduce expenditure, and on the other side is an average of 13 credit providers who all want their money. ${ }^{9}$

The research report by the Law Clinic mentioned above, indicated that credit providers and debt counsellors not co-operating in the debt counselling process were one of the main reasons for the non-functioning of the process. ${ }^{10}$ In this regard it should be noted that section 86(5) of the NCA compels consumers and credit providers to "participate in good faith in the review and in any negotiations designed to result in responsible debt rearrangement". The report has shown however, that credit providers and to a lesser degree debt

$7 \quad$ See Haupt, Roestoff and Erasmus (n 1) 17.

8 Kelly-Louw 2008 SAMercLJ 200-226; Du Plessis 2007 JJS 77.

9 Gillingham Sunday Times 21.

10 Out of the 64 debt counsellors interviewed, 36\% indicated that they had experienced problems with consumers not co-operating, while $72 \%$ experienced problems with credit providers not co-operating. Haupt, Roestoff and Erasmus (n 1) 307. 
counsellors, were not acting in good faith in the debt counselling process. ${ }^{11}$ Moreover, the report indicated that non-compliance with the NCA and Regulations as well as a breach of the so-called work stream agreement ${ }^{12}$ were important causes of the ineffectiveness and the non-functioning of the debt counselling process. ${ }^{13}$ The work stream agreement flowed from the fact that the debt review process and the exact procedure to be followed are not fully regulated in the Act or Regulations. Therefore, major credit providers ${ }^{14}$ in consultation with established debt counsellors and the NCR at various work stream sessions, agreed to certain guidelines which should be followed in order to streamline the debt counselling procedure.

The following reasons have inter alia been indicated by the South African Media for the ineffectiveness of the debt counselling process:

(a) A sharp increase in the number of consumers applying for debt review and a concomitant shortage of competent debt counsellors. ${ }^{15}$

(b) Many debt counsellors trained and registered by the NCR do not practice because it is not feasible for them to do so. ${ }^{16}$

(c) Consumers are still uneducated on the objectives of the debt review process. Debt counsellors often fail to inform consumers of the consequences of debt counselling. Consequently many consumers are under the erroneous impression that debt counselling affords them a payment holiday. ${ }^{17}$

11 Debt counsellors' perceptions were that $61 \%$ of credit providers were acting in bad faith, while on the part of consumers a rate of $35 \%$ was recorded. Haupt, Roestoff and Erasmus (n 1) 304-305.

12 Cf Da Silva et al 2008 www.ncr.org.za/ 5 et seq. This document, which was published in July 2008, contains the 'work stream guidelines' agreed to by most of the major credit providers, established debt counsellors and the NCR.

13 Cf Haupt, Roestoff and Erasmus (n 1) 113 et seq and 230 et seq.

14 Absa Bank, African Bank, First National Bank, Nedbank, Standard Bank, Wesbank and the Motor Financing Corporation

15 Stewart Daily Dispatch 11; Gerretsen Saturday Weekend Argus 12. The report by the Law Clinic listed incompetent debt counsellors as one of the major obstacles in the debt review process. $27 \%$ of debt counsellors interviewed attributed problems in the debt counselling process to incompetent debt counsellors. Haupt, Roestoff and Erasmus (n 1) 307.

16 Naidu Sunday Independent 1.

17 Khanyile Star 20; Jackson Mail and Guardian 39. 
(d) Consumers are often not willing to accept that they cannot maintain the same standard of living that got them into their financial predicament in the first place. ${ }^{18}$

(e) Credit providers fail to take responsibility for the negative consequences of credit granting and do not appreciate the fact that they will have to take losses and write off debts. ${ }^{19}$

(f) Although an application for debt review precludes credit providers from taking legal action against the consumer, nothing stops the credit provider from pursuing the debt. ${ }^{20}$

(g) The amount of debt concerned ${ }^{21}$ often does not justify the legal costs that will be incurred to take the matter to court. ${ }^{22}$

(h) Legal uncertainty exists regarding the interpretation of the NCA's provisions pertaining to the debt counselling process. ${ }^{23}$

According to the research report of the Law Clinic vagueness and insufficiency of the NCA and Regulations were second on the list of so-called major obstacles in the debt counselling process. ${ }^{24}$ Uncertainty regarding the interpretation of the NCA's provisions pertaining to the debt counselling process also urged the NCR to apply for a declaratory order in terms of section $16(1)(b)(i i)$ of the NCA. ${ }^{25}$

In this article the formal debt counselling process introduced by the NCA and Regulations as well as the agreements reached between various role players in the credit industry will be investigated. In this regard the office of the debt

Van Zyl Sake Rapport 8.

24 Credit providers not co-operating headed the list ( $72 \%$ of debt counsellors interviewed mentioned this as the main problem). This was followed by insufficiency of the Act and Regulations (53\%), consumers not co-operating (36\%) and incompetent debt counsellors (27\%). Those who chose 'other' as a major problem (23\%) mentioned payment distribution agencies not performing and magistrates' lack of experience and knowledge of the Act as main problems. Haupt, Roestoff and Erasmus (n 1) 307.

25 National Credit Regulator $v$ Nedbank Ltd Case no 19638/08 (TPD) (unreported). This matter has been heard but judgment has not been delivered yet. 
counsellor, the debt review process as well as other related problematic issues will be investigated. The aim is to identify the loopholes in the NCA and Regulations which cause the lack of legal certainty and which contribute to the apparent ineffectiveness of the debt counselling process. Proposals to remedy these deficiencies will also be made.

\section{The debt review process and related issues}

\subsection{The office of the debt counsellor}

\subsubsection{The functions of a debt counsellor}

One of the main purposes of the NCA is to provide debt relief to the overindebted consumer, ${ }^{26}$ by affording the consumer the opportunity to survive the immediate consequences of his or her financial predicament and to attain a manageable financial position. ${ }^{27}$ The success of the Act's provisions in this regard depends to a great extent on the effectiveness of the debt counselling process and the debt counsellor whose principal function is to assist the overindebted consumer with the process of debt review as prescribed in section 86 of the Act. ${ }^{28}$

26 Cf s 3(g) and (i) of the NCA. It should be noted that the Act only applies to a consumer who is a party to a credit agreement ito the Act. See s 4(1); Renke, Roestoff and Haupt 2007 Obiter 229-270 and Stoop 2008 De Jure 352-370 for a discussion of the field of application of the Act. See also Roestoff and Renke 2006 Obiter 98-110 for a discussion of alternative debt relief measures ito the Insolvency Act 24 of 1936, the Magistrates' Courts Act 32 of 1944 (MCA) (s 74 administration orders) and the proposed pre-liquidation composition (by the SALRC) and the interaction between these measures. Also see Boraine "Reform" 187-216. In Ex parte Ford and Two Similar Cases 2009 (3) SA 376 (WCC) 383 A-B the court refused to exercise its discretion in favour of the applicants for an order for the voluntary surrender of the respective applicants' estates. The court found that debt review ito the NCA was the more appropriate debt relief mechanism to be used as the major portion of the applicants' debt arose out of credit agreements ito the NCA.

27 First Rand Bank Ltd v Olivier [2008] JOL 22138 (SE) 6; Standard Bank of SA Ltd v Panayiotts Case no 08/00146 (WLD) (unreported) par 81.

28 Cf Kelly-Louw (n 8) 225. The Act does not define the concept 'debt counselling' but the regulations define it as "performing the functions contemplated in section 86 of the Act", which refers to the debt review process. 
As pointed out by Du Plessis, ${ }^{29}$ the duty of a debt counsellor is specifically outlined in the Act. Therefore, interference in the affairs of a consumer is not permitted. A debt counsellor cannot give financial advice to a consumer regarding investments, insurance and purchasing or variation of financial products, unless he is registered with the Financial Services Board as a financial advisor in terms of the Financial Advisory and Intermediary Services Act (FAIS). ${ }^{30}$ Du Plessis ${ }^{31}$ points out however, that a debt counsellor is not precluded from consulting with a consumer without providing financial advice. In terms of section 86(5) of the NCA a consumer who has applied for debt review must

comply with any reasonable request by the debt counsellor to facilitate the evaluation of the consumer's state of indebtedness and the prospects for responsible debt rearrangement.

Moreover, a debt counsellor is also not precluded from making suggestions regarding the debtor's investments in the recommendation to the Magistrate's Court in terms of section 86(7) of the Act. ${ }^{32}$ Du Plessis ${ }^{33}$ however poses the question as to what would prevent a debt counsellor from also being registered as a financial advisor in terms of FAIS and thereby being able to charge a client a fee for both the debt counselling and the financial counselling. In our view, this may however lead to a conflict of interests which the debt counsellor, who should act professionally, must avoid. ${ }^{34}$

In addition to his duty to perform the functions in terms of section 86 of the Act, the Act also requires the debt counsellor to keep certain records ${ }^{35}$ and to maintain certain information in a register ${ }^{36}$ which may be in electronic format. ${ }^{37}$

29 Du Plessis (n 8) 79.

30 Act 37 of 2002.

31 Du Plessis (n 8) 79.

32 Ibid.

33 Du Plessis (n 8) 81.

34 Cf Da Silva et al (n 12) 5 et seq.

$35 \mathrm{Eg}$ the application for debt review iro each consumer, the debt restructuring proposals and copies of documents submitted by consumers - reg 55(1)(a).

$36 \mathrm{Eg}$ the consumer's full names and surname, the date of application for debt review, the status of the case, etc - reg 60(1).

37 See in general Du Plessis (n 8) 89. 
The debt counsellor also has a duty to submit a compliance report in Form 41 to the NCR by the $15^{\text {th }}$ of February each year as well as a statistical return in Form 42 every quarter. ${ }^{38}$

\subsubsection{Registration of debt counsellors}

'Debt counsellor' in terms of regulation 1 "means a neutral ${ }^{39}$ person who is registered in terms of section 44 of the Act offering a service of debt counselling". A person may not offer debt counselling-services unless he or she is registered as a debt counsellor by the NCR, the regulatory body of all debt counsellors. $^{40}$ Only natural persons ${ }^{41}$ may apply to be registered as debt counsellors and must satisfy certain prescribed requirements relating to education, $^{42}$ experience and competence, or satisfy within a reasonable time, such requirements as the NCR may determine as a condition to the applicant's registration. ${ }^{43}$ With regard to experience and competence, regulation $10(\mathrm{~b})$ requires a debt counsellor to have at least two years working experience in any of the following fields: ${ }^{44}$

(a) consumer protection, complaints resolution or consumer advisory services;

(b) legal or paralegal services;

(c) accounting or financial services;

(d) education or training of individuals;

(e) counselling of individuals;

(f) general business environment.

38 Reg 69. Also see Du Plessis (n 8) 90.

39 The NCA or Regulations does not define a neutral person. S 44 makes provision for only natural persons to be registered. It would therefore appear that reg 1 intended to refer to a natural person.

40 S 45 and 44(2). See on the registration of debt counsellors in general Vessio 2008 SAMerCLJ 238.

$41 \mathrm{~S}$ 44(1).

42 Reg 10(a) requires a Grade 12 certificate or equivalent Level 4 qualification issued by the SAQA and the successful completion of a debt counselling course approved by the NCR and provided by an institution approved by the NCR.

43 S 44(3). See also s 48(2) and (3).

44 Scholtz et al Credit Act 11-7 $\mathrm{n} 33$ points out that it is unnecessary to have experience in all these fields. Experience in one of them is sufficient. 
In addition, a debt counsellor must also have demonstrated the ability to manage their own finances when applying for registration and to provide counselling or transfer skills. ${ }^{45}$ Du Plessis ${ }^{46}$ points out that the regulations are silent as to how a person's ability to manage his own affairs will be measured. The question arises as to whether this will be measured purely by the fact that such a person is not registered with a credit bureau for bad debt? The regulation is also silent on the measuring of a person's ability to transfer skills or provide counselling. The criteria are also criticised for requiring no higher education or technical expertise from the debt counsellor. ${ }^{47} \mathrm{~A}$ debt counsellor must have sufficient knowledge in order to best protect his or her client's interests. ${ }^{48}$ A further question therefore arises as to whether a review of the requirements pertaining to education, experience and competence of debt counsellors have not become necessary as one of the reasons indicated for the ineffectiveness of debt counselling has indeed been the shortage of competent, experienced and knowledgeable debt counsellors. ${ }^{49}$

The Regulator will not register a debt counsellor if any of the disqualifying criteria in terms of sections 46 and 47 apply to the applicant. For example, in terms of section 46(4)(c) a person may not register as a debt counsellor if such a person is engaged in, employed by or acting as an agent for a person engaged in debt collection, ${ }^{50}$ the operation of a credit bureau, credit provision or any other activity prescribed by the Minister on grounds of conflict of interest. It should be clear that this provision was inserted to avoid a conflict of interest between a person's duty to act in the best interest of a consumer as a debt

45 Reg 10(b)(ii).

46 Du Plessis (n 8) 76.

47 Ibid.

48 Da Silva et al (n 12) 7.

49 Cf Stewart (n 15) 11; Haupt, Roestoff and Erasmus (n 1) 307.

50 Du Plessis (n 8) 77 n 4 points out that this provision disqualifies a sizeable number of attorneys and paralegals and raises the question whether this exclusion will apply to nongovernmental organisations assisting the indigent and law clinics whose main function is not debt collection, but who may attend to a few such cases at any given time. 
counsellor, and a person's duty to act in the best interest of the credit provider or debt collector, as the case may be. ${ }^{51}$

Before registration will be effected the NCR will require the debt counsellor to sign certain conditions for registration which, inter alia, states the following: ${ }^{52}$

(a) The debt counsellor must fulfil his duties in a manner which is consistent with the purpose and requirements of the Act.

(b) In providing debt counselling the debt counsellor must act professionally, reasonably and in a manner that is fair and nondiscriminatory.

(c) The debt counsellor must act in the best interest of the consumer and refrain from taking part in activities which could lead to a conflict of interests.

(d) The debt counsellor may not charge or recover fees apart from those allowed in terms of the Act and Regulations.

(e) Except with the written permission of the consumer the debt counsellor may not disclose any information relating to the consumer to a third party.

Any complaints or queries concerning debt counsellors must be lodged with the NCR. If a complaint is lodged against a debt counsellor, the NCR may issue the debt counsellor with a compliance notice and if the debt counsellor fails to remedy the default, the NCR may apply to the National Consumer Tribunal to have the debt counsellor deregistered. ${ }^{53}$

\subsection{The debt review process}

\subsubsection{Initiation of the debt review process}

In terms of section 86(1) a consumer who is of the opinion that he is overindebted may apply to a debt counsellor in the prescribed manner and form to

51 Da Silva et al (n 12) 6.

52 Da Silva et al (n 12) 9-10.

53 Cf s 14(b), 15(b), (e), (i) and 57(1). 
have him declared over-indebted. One of the first steps in the debt review process is therefore, a determination by the debt counsellor whether the consumer is over-indebted, likely to become over-indebted, or not overindebted at all. ${ }^{54}$ Furthermore, if it is alleged in any court proceedings in which a credit agreement is considered ${ }^{55}$ that the consumer is over-indebted, the court $^{56}$ is in terms of section 85 given the power to either refer the matter to a debt counsellor, ${ }^{57}$ or to declare and relieve ${ }^{58}$ the over-indebtedness. ${ }^{59}$ Consumers who are over-indebted may therefore apply for debt review themselves or alternatively wait for a credit provider to enforce a credit agreement in respect of which the consumer is in default, and then raise the issue of over-indebtedness in court. ${ }^{60}$ In this regard, the court, in the Panayiotts case, ${ }^{61}$ held that a mere allegation of over-indebtedness is not sufficient. The over-indebtedness should be established on a balance of probabilities as envisaged in section 79(1) which refers to "the preponderance of available information at the time a determination is made". ${ }^{62}$

54 S 86(6) and (7) and see the discussion in par 2.2.4 and 2.2.5 below.

55 In Ex parte Ford and Two Similar Cases 2009 (3) SA 376 (WCC) 381 F-H, the court found that the application of $s 85$ is not restricted to proceedings in which the enforcement of a credit agreement is the issue and that it would also be applicable in proceedings for voluntary surrender under the Insolvency Act.

56 Scholtz et al ( $n$ 44) 11-17 point out that s 85 refers to the word 'court' which suggests that any court (ie also the High Court) can declare and relieve over-indebtedness. They suggest however, that if $s 85$ is read together with the sections it refers to (s 86(7) and 87), it should be clear that the legislature intended that the actual debt restructuring process should be dealt with by the Magistrate's Court.

57 Ito $\mathrm{s} 85(\mathrm{a})$ the debt counsellor should be requested to evaluate the consumer's circumstances and make a recommendation to court ito s $86(7)$.

58 Ito $\mathrm{s} 87$.

59 S 85(b).

60 Scholtz et al (n 44) 11-6. Cf the Panayiotts case par 3. In the Panayiotts case par 28 et seq the court pointed out that the consumer must however, in such a case, explain his failure to approach a debt counsellor prior to litigation as it is undesirable that the more costly procedure of the High Court should be implemented and that the High Court should deal with frequent applications for debt restructuring along the lines of a s 65 court. Furthermore, the High Court should not deal with a matter where there is an alternative, simple and effective procedure available (in casu the debt review procedure ito s 86 ). Cf also the Olivier case 10 et seq. In Olivier the court found that the defendant's case for a s 85 order was not persuasive as he did not explain his failure to approach a debt counsellor prior to litigation. In the Panayiotts case (par 37) the court however granted condonation as the s 129 notice, although properly served, did not come to the notice of the defendant.

61 Par 24, 42 and 55.

62 See par 2.2.4 for a discussion of $\mathrm{s} 79$. 
If a consumer alleges in the High Court that he is over-indebted and the High Court refers the matter to a debt counsellor in terms of section 85(a), the recommendation that the debt counsellor has to make to the court in terms of section 86(7) must be made to the relevant High Court who must also deal with the matter in terms of section $86(7)(c) .{ }^{63}$ In the Panayiotts case, ${ }^{64}$ the court pointed out that section 85(a) requires the debt counsellor to make a recommendation "to the court", which is not limited to the Magistrate's Court and is therefore clearly a reference to the court which referred the matter to the debt counsellor. The court explained as follows:

Any other interpretation could lead to absurdity, since, if different courts were involved, a Magistrates' Court would be adjudicating a matter whilst it is pending in the High Court. The element of policing would also be problematic, since the High Court would not necessarily know if its request has been heeded and carried out in the Magistrates' Court. ${ }^{65}$

If the High Court in terms of section 85(b) elects to declare that the consumer is over-indebted, the power to relieve the consumer's over-indebtedness in terms of section 87 would fall on the relevant High Court in which the defence was raised. ${ }^{66}$

It should be noted that only a court can declare a consumer to be overindebted. ${ }^{67}$ A debt counsellor's function in terms of section 86(6)(a) is merely to conduct a debt review in order to determine whether a consumer appears to be over-indebted. ${ }^{68}$ Should the consumer seek a declaration of reckless credit, the

63 Panayiotts case par 19. Cf however Scholtz et al (n 44) 11-18 who are of the view that the recommendation has to be made to the Magistrate's Court.

64 Par 17.

65 Par 18.

66 Panayiotts case par 21. Also see s 130(4)(c)(ii)-(iii) which, in our view, provides further support for the interpretation in the Panayiotts case that any court (ie also the High Court) can declare and relieve over-indebtedness ito s 85. Scholtz et al (n 44) 11-29 suggest that the matter in such a case should be referred to the Magistrate's Court for debtrearrangement. They suggest that such referral will probably have to be done ito the inherent jurisdiction of the High Court as there are no designated procedure for it. R 39(22) pertains to the monetary value of a claim and is therefore not applicable.

67 Scholtz et al (n 44) 11-6.

68 Ibid. 
debt counsellor is also in terms of this section ${ }^{69}$ empowered to determine whether any of the consumer's credit agreements appear to be reckless. ${ }^{70}$

\subsubsection{The first consultation and the taking of instructions}

As pointed out above,$^{71}$ the practical execution of the debt review process and the exact procedure to be followed is not fully regulated in the Act or Regulations. Consequently, major credit providers in consultation with established debt counsellors and the NCR at various work stream sessions, agreed to certain guidelines which should be followed in order to streamline the debt counselling procedure. ${ }^{72}$ According to these guidelines the first consultation with the consumer should first of all inform the client of what debt review entails and how the process works. The following matters should also be explained to the consumer: ${ }^{73}$

(a) Which information and documentation the consumer is required to submit to the debt counsellor and that this information will be verified by the debt counsellor.

(b) The consequences of debt review. In this regard, the debt counsellor must explain to the consumer that he may not enter into any further credit agreements for the duration of the debt review process. The consumer may also not incur any further charges, by for example, using an overdraft facility or credit card. Credit cards, store cards and garage cards must be destroyed.

(c) The time constraints applicable to the process.

(d) The rights of the consumer and credit providers during the debt review process.

(e) The effect of debt review on the consumer's joint household. ${ }^{74}$

69 S 86(6)(b).

70 See in this regard s 80-84 and in general regarding reckless credit granting Scholtz et al (n 44) 11-19 et seq.

71 Par 1.

72 Scholtz et al (n 44) 14-2 n 2; Da Silva et al (n 12) 3.

73 Scholtz et al (n 44) 14-2 et seq; Da Silva et al (n 12) 13.

74 It should be noted that the income of the spouse to whom a consumer are married in community of property should be included when a determination with regard to overindebtedness ito $s$ 86(6) are made and a joint debt review application should be made. If 
(f) The implications of debt review on the consumer's standard of living as well as his living expenses.

(g) Listing at credit bureaux and the consequences thereof.

(h) The consumer's responsibility to continue with interim payments until a court or tribunal order has been made. Insurance premiums for assetfinance and vehicle finance agreements, mortgage loans and life cover should be paid in full.

(i) The costs that are involved, that is, the debt counsellor's fee ${ }^{75}$ and if applicable, the fee of the attorney when the matter is referred to court.

(j) All credit agreements must be included.

As soon as the consumer has been informed of what the debt review process entails and if the consumer indicates that he wishes to proceed with the process, the debt counsellor will explain and assist the consumer in completing and signing Form 16, which forms the basis of the client's instructions. ${ }^{76}$ The debt counsellor may then charge the consumer a R50 application fee, whereupon the debt counsellor provides the consumer with a receipt as proof of the application ${ }^{77}$ for debt review as well as a copy of the Form 16 for the consumer's own records. ${ }^{78}$

As pointed out above,$^{79}$ one of the perceived reasons why the debt counselling process appears to be ineffective is the fact that debt counsellors do not properly inform consumers about what the process and its consequences entail. In order to ensure that consumers are properly informed, it is suggested that a revised Form 16, which deals with the matters listed above more comprehensively, could help to ensure that consumers are properly informed of the consequences of debt review.

the parties are married out of community of property or are living together, a joint exposition of income should be provided in order to prevent the situation of one party being liable for all debt while the other party's income is used by both to fund a comfortable and luxurious lifestyle - cf Da Silva et al (n 12) 22 and also s 78(3)(b).

75 See the discussion below.

76 Cf Da Silva et al (n 12) 15 and Scholtz et al (n 44) 14-3.

77 S 86(4)(a).

78 Da Silva et al (n 12) 15.

79 Par 1. 
It is also important that the debt counsellor informs the consumer of the effect of section 86(2) when he applies for debt review. ${ }^{80}$ This subsection provides that an application for debt review in terms of section 86

may not be made in respect of, and does not apply to a particular credit agreement if, at the time of the application, the credit provider under that credit agreement has proceeded to take the steps contemplated in section 129 to enforce the agreement.

In terms of the Act, a credit provider may, under part C of chapter 6 of the NCA commence legal proceedings to 'enforce' the agreement. The Act however does not define the concept of enforcement, and the question arises whether enforcement of a credit agreement means the exercise of any of his remedies by a credit provider ${ }^{81}$ Van Loggerenberg et al ${ }^{82}$ submit that even though part $\mathrm{C}$ sets out the requirements for debt enforcement by repossession or judgment 'debt enforcement' under part $C$ also includes cancellation of the agreement and an accompanying claim to repossess the goods. The phrase 'debt enforcement' should therefore not be interpreted to mean enforcement of a contract by means of a claim for specific performance only, and a notice in terms of section 29(1)(a) ${ }^{83}$ would also be required if the credit provider elects to cancel the agreement. ${ }^{84}$

It is submitted that enforcement commences upon the issuing and service of a summons, after the credit provider has complied with the requirements set out in section 129(1) ${ }^{85}$ read with 130(1) of the Act. ${ }^{86}$ Moreover, a section 129(1)(a)

80 Da Silva et al (n 12) 13

81 Cf Otto National Credit Act explained 87-88; Scholtz et al (n 44) 12-2; Boraine and Renke 2007 De Jure 224; Boraine and Renke 2008 De Jure 2.

82 Van Loggerenberg, Dicker and Malan 2008 De Rebus 40-44.

83 See the discussion below.

84 Boraine and Renke 2008 De Jure 2. In this regard the wording of s 123(2) and 129(3)(a) is relevant as it provides that a credit provider may take the steps set out in Ch 6 Part C to enforce and terminate an agreement. Cf Otto (n 81) 88; Boraine and Renke 2008 De Jure 2; Van Loggerenberg, Dicker and Malan (n 82) 40.

85 It should be noted that compliance with s 129(1) is not required if a consumer is in default with regard to a credit agreement that is subject to debt review or debt rearrangement and the credit provider wants to enforce that agreement. See s 129(2) and Boraine and Renke 2008 De Jure 2 n 15. 
notice delivered to a consumer by a credit provider does not constitute enforcement, as the heading to section 129 refers to "Required procedures before debt enforcement". ${ }^{87}$ Section 129(1)(a) provides that

if the consumer is in default under a credit agreement the credit provider may ${ }^{88}$ draw the default to the notice of the credit provider in writing and propose that the consumer refer the credit agreement to a debt counsellor, alternative dispute resolution agent, consumer court or ombud with jurisdiction, with the intent that the parties resolve any dispute under the agreement or develop and agree on a plan to bring the payments up to date... ${ }^{89}$

It would therefore appear that the legislator's reference to section 129 in section 86(2) is a reference to the commencement of legal proceedings mentioned in section $129(1)(b)^{90}$ and that a consumer should not be precluded from applying for debt review in respect of the specific credit agreement after receipt of a section 129(1)(a) notice. ${ }^{91}$ Section 129(1)(b) provides that, subject to section 130(2) a credit provider may not commence any legal proceedings to enforce

86 Da Silva et al (n 12) 14; Van Loggerenberg, Dicker and Malan (n 82) 40. Boraine and Renke 2008 De Jure 9 are of the view that enforcement commences as soon as summons is issued and that the consumer is then precluded from applying for debt review.

87 Cf Van Heerden and Otto 2007 JSAL 667; Van Loggerenberg, Dicker and Malan (n 82) 40; Da Silva et al (n 12) 14; Scholtz et al (n 44) 11-9.

88 Scholtz et al ( $n$ 44) 12-7 points out that the word 'may' is misleading as it might create the impression that the credit provider is not obliged to comply with the procedure contemplated in s 129(1)(a). If, however, s 129(1)(a) is read together with s 129(1)(b) and 130(1) it should be clear that compliance is indeed required. Cf also Absa Bank Ltd v Prochaska Case no 14839/2007 (D) (unreported) par 35 and Boraine and Renke 2008 De Jure 3 n 16.

89 Regarding the purpose of s 129(1)(a) it was suggested in the Prochaska case that it "is a mechanism created by the Act to enable the consumer to take one or other of those steps proposed by the credit provider in the notice in terms of the subsection, before the credit provider commences litigation". Further to this, Boraine and Renke 2008 De Jure 9 n 64 submit that the s 129(1)(a) notice "has as purpose to inform the consumer about his or her right to apply for debt review". Its purpose is further to "encourage parties to iron out their differences before seeking court intervention ... this view ... tallies with the overall purpose of the National Credit Act, which is mainly to protect the consumer - in this instance against costly and protracted litigation". Scholtz et al (n 44) 12-8. The last-mentioned authors (12-7) point out that $s$ 129(1)(a) does not limit this requirement to claims for return of goods only and does not specify the type of agreement to which this section applies. Consequently, in all cases where the consumer is in default, regardless of the type of credit agreement, delivery of the s 129(1)(a) notice will be compulsory.

90 Cf par 69-71 of the founding affidavit to the NCR's application for a declaratory order ito $s$ 16(1)(b)(ii) of the NCA (hereafter NCR: Founding Affidavit) National Credit Regulator $v$ Nedbank Case no 19638/08 (TPD) (unreported).

91 Cf Scholtz et al (n 44) 12-6. 
the agreement ${ }^{92}$ before first providing notice to the consumer in terms of section 129(1)(a) or ${ }^{93}$ section $86(10)$, as the case may be, and complying with any further requirements set out in section 130 .

In the case of Frederick $v$ Greenhouse Funding (Pty) $L t d,{ }^{94}$ the court however found that the only step which a credit provider can take in terms of section 129 , is the step in section 129(1)(a) namely, the sending of the letter. The court rejected the argument that the sending of the letter is not a step to enforce the agreement and found with reference to the matter of Nedbank Ltd v Motaung: ${ }^{95}$

If section 86(2) is read to mean that the sending of the letter is not a step under section 129 to enforce the agreement, then the section is rendered nugatory. In my view a proper interpretation must be provided to the section. The section must be interpreted so as to not have an absurd result and so as to reflect commercial reality. Such an interpretation would involve an interpretation of Section 86(2) as meaning that the sending of a letter constitutes a step contemplated in Section 129 to enforce the agreement. ${ }^{96}$

It is submitted that the interpretation of the court does not take into consideration the content of section 129(1)(a) namely that the credit provider may propose to the consumer that he refer the relevant credit agreement to a debt counsellor. It does not make sense to propose to the consumer to approach a debt counsellor and at the same time also preclude the consumer from applying for debt review. ${ }^{97}$ As a matter of fact, it would therefore appear that the interpretation the court attributes to section 86(2) actually leads to an absurd result. To clarify the uncertainty with regard to the question as to when enforcement for the purposes of section 86(2) commences, it is submitted that

92 These words mean "the actual institution of an action or the launching of an application to uphold, enforce, compel observance of or compliance with any obligation arising from a credit agreement". See the Prochaska case par 27.

93 The institution of legal proceedings must therefore be preceded by either a s 129(1)(a) or a s 86(10) notice. Boraine and Renke 2008 De Jure 3. A s 129(1)(a) notice is required in instances where the matter is not subject to debt review, while a s 86(10) notice is required in instances where debt review is already under way. Boraine and Renke 2008 De Jure 4.

94 Case no 31825/2008 (WLD) (unreported).

95 Case no 22445/07 (TPD) (unreported).

96 See $\mathrm{p} 4$ of the typed manuscript.

97 Cf also Van Loggerenberg, Dicker and Malan (n 82) 40; Boraine and Renke 2008 De Jure 9 n 61; NCR: Founding Affidavit par 70. Contra Otto (n 81) 85. 
section $86(2)$ should be amended by substituting the words 'section 129' with 'section 130'. 98

In terms of section 130(1) a credit provider may only approach the court for an order to enforce a credit agreement, if,

(a) at that time the consumer is in default and has been in default under that credit agreement for at least 20 business days, ${ }^{99}$ and

(b) at least 10 business days have elapsed since the credit provider delivered a notice to the consumer in terms of section $86(10),{ }^{100}$ or section 129(1), as the case may be, ${ }^{101}$ and

(c) in the case of a notice in terms of section 129(1), the consumer has not responded to the notice, ${ }^{102}$ or responded by rejecting the credit provider's proposals, ${ }^{103}$ and

(d) in the case of an instalment agreement, secured loan, or lease, the consumer has not surrendered the relevant property to the credit provider as contemplated in section $127 .{ }^{104}$

The two pre-requisites that should be complied with before a credit provider can commence with enforcement proceedings ${ }^{105}$ are therefore to be found in section $129(1)$ read with section $130(1):^{106}$

98 Cf also Van Heerden and Otto (n 87) 668.

99 S 130(1)(a).

100 The Act refers to s 86(9) which is submitted to be wrong. Cf Scholtz et al (n 44) 12-5 n 37 and Boraine and Renke 2008 De Jure $6 \mathrm{n}$ 32. S 86(10) is discussed in par 2.2.7 below.

101 S 130(1)(a).

102 S 130(1)(b)(i). Also see Absa Bank Ltd v Whelpton Case no 35313/2008 (TPD) (unreported) par 11 et seq. Although the court did not specifically refer to s 130(1)(b)(i) it appears that the court applied this subsection to the facts in casu. The court held that despite a valid section 129(1)(a) notice and the institution of action thereafter, the credit provider was precluded from proceeding with enforcement of the credit agreement concerned in circumstances where the evidence proved that the parties agreed to postpone the matter with the view to enter negotiations relating to a repayment plan and debt rescheduling ito the NCA.

103 S 130(1)(b)(ii).

104 S 130(1)(c).

105 It should be noted that a s 129(1)(a) notice is also a prerequisite before a credit provider may proceed to apply for judgment on the basis of the consumer's consent to judgment in terms of s 57 or 58 of the MCA. See Scholtz et al (n 44) 12-44. S 129 prevails over s 57 and 58. See s 172 (1) and Sch 1 to the Act. 
(a) A section 129(1)(a) notice or a section 86(10) notice should have been delivered to the consumer at least 10 business days ${ }^{107}$ prior to enforcement proceedings, and

(b) The consumer is in default under that credit agreement for at least 20 business days, which two periods may run concurrently. ${ }^{108}$

It should however be noted that a credit provider must additionally also comply with the other requirements set out in section $130 .{ }^{109}$ So, for example, section 130(3)(c)(i) precludes the court from determining a matter unless it is satisfied, inter alia that the credit provider has not approached the court during the time that the matter was before a debt counsellor. Additionally, in terms of section 130(3)(c)(ii), the credit provider is also prevented from approaching the court in respect of a credit agreement to which the Act applies, where the consumer has taken and fulfilled any of the steps mentioned in section 129(1)(a). ${ }^{110}$

According to the Prochaska case the NCA represents a radical departure from its predecessor, the Credit Agreements Act (CAA), ${ }^{111}$ with regard to the notice in terms of section $129(1)(a) .{ }^{112}$ Whereas the CAA merely required the credit receiver to notify the creditor of his default by prepaid registered mail, section 129(1)(a) requires the credit provider to "draw the default to the notice of the consumer in writing". ${ }^{113}$ Section 129(1)(b) precludes the credit provider from

106 Da Silva et al (n 12) 14; Standard Bank of SA Ltd v Oosthuizen [2008] JOL 22036 (T) 7; Visagie 2006 De Rebus 21-23.

107 Scholtz et al (n 44) 12-8 point out that s 129(1)(a) does not indicate any time limits applicable to the section itself. The 10 days requirement is derived from $s$ 130(1)(a). They submit however, that a s 129(1)(a) notice should expressly state that a response is required within 10 business days from delivery of the notice. Also see Van Heerden and Otto (n 87) 662.

108 Da Silva et al (n 12) 14; Otto (n 81) 91; Scholtz et al (n 44) 12-21.

109 S 129(1)(b)(ii). Cf Visagie (n 106) 21 et seq.

110 If the court determines that the credit provider has indeed approached the court in circumstances contemplated in subs 3(c) the court must adjourn the matter and make an appropriate order setting out the steps the credit provider must complete before the matter may be resumed. $\mathrm{S} 130(4)(\mathrm{b})$.

111 Act 75 of 1980.

112 Prochaska case par 55. See in general with regard to the requirements for a s 129(a) notice Scholtz et al (n 44) 12-6 et seq, Van Heerden and Otto (n 87) 658 et seq; Boraine and Renke 2008 De Jure 3 et seq.

113 Prochaska case par 55. 
commencing any legal proceedings to enforce the agreement before 'providing notice' to the consumer in terms of section 129(1)(a). ${ }^{114}$ Further to this, a credit provider may only approach a court for an order to enforce an agreement if, inter alia at least 10 business days have elapsed since a credit provider 'delivered a notice', as contemplated in section 129(1)(a) of the Act, to the consumer. ${ }^{115}$ According to the court in the Prochaska case, the words emphasised

cumulatively reflect an intention on the part of the legislature to impose upon the credit provider an obligation which requires much more than the mere dispatching of the notice contemplated by section 129(1)(a) of the Act, to the consumer in the manner prescribed in the Act and Regulations. The credit provider is required, in my view, to bring the default to the attention of the consumer in a way which provides assurance to a court considering whether or not there has been proper compliance with the procedural requirements of section 129 and 130 of the Act, that the default has indeed been drawn 'to the notice of the consumer. ${ }^{116}$

Regarding the fee of a debt counsellor, section 86(3)(a) provides that the debt counsellor may, before accepting a debt review application require the consumer to pay an application fee which may not exceed the prescribed amount. Currently schedule 2 of the regulations merely provides that -

an application fee charged by a debt counsellor to a consumer when applying for debt restructuring may not exceed R50.00.

One of the initial concerns after commencement of the NCA was that the prescribed fee for debt counsellors is so dismal that no one would be willing to practise as a debt counsellor. ${ }^{117}$ As a result, a recommended cost and fee structure was drafted by the Debt Counselling Association of South Africa (DCASA) which was endorsed by the NCR. To date however, the regulations remain unchanged. It is submitted that the uncertainty pertaining to debt counsellors' fees and the problem of possible overcharging of consumers should be resolved by specifically prescribing the fees that may be recovered 
by debt counsellors. Section 86(3)(b) currently provides that a debt counsellor may not require or accept a fee from a credit provider in respect of a debt review application. It has been suggested that credit providers should also bear some of the debt counselling costs, since the restructuring of consumer debt would enable them to recover claims. ${ }^{118}$ It is suggested, that the legislator should consider the amendment of section 86(3) to provide for this possibility.

\subsubsection{Notification of credit providers and credit bureaux}

The debt counsellor must deliver a completed Form $17.1^{119}$ within five business days after receiving the debt review application to all credit providers ${ }^{120}$ that are listed in the application and every registered credit bureau. ${ }^{121}$ This ensures that credit providers are notified of the consumer's application for debt review and prevents them from entering into further credit agreements whilst the consumer is under debt review. It also prevents reckless credit granting in terms of section $88(4){ }^{122}$

In terms of regulation 24(3), the debt counsellor must verify the information provided by the consumer in terms of regulation 24(1), by requesting documentary proof from the consumer. The debt counsellor must also contact the relevant credit providers or employer or utilise any other method of verification. ${ }^{123}$ If the credit provider fails to provide the requested information within five business days of such verification being requested, the debt counsellor may accept the information provided by the consumer as correct. ${ }^{124}$

118 Du Plessis (n 8) 90-91.

119 The debt counsellor may provide the consumer's address and contact details on this form only if the debt counsellor has obtained the consumer's written consent. The address will however not be deemed as an amendment to the consumer's domicilium address. Da Silva et al (n 12) 15.

120 See the "Credit Provider List" which contains their addresses and other contact details. Debt counsellors who deliver proposals to these addresses have a much better chance of a speedy response. Da Silva et al (n 12) 16.

121 Cf s 86(4)(b) read with reg 24(2). Ito reg 24(5) this notice must be sent by fax, registered mail or e-mail, provided that the debt counsellor keeps a record of the date, time and manner of delivery of the notice.

122 Scholtz et al (n 44) 14.9 et seq.

123 Reg 24(3).

124 Reg 24(4). Ito the work stream guidelines the debt counsellor should send a reminder to the credit provider if no response has been received after the five days period. Such 
Credit providers, who are work stream participants, have undertaken to provide a 'Certificate of Balance' ${ }^{125}$ which contains the following important financial information pertaining to the credit agreement: ${ }^{126}$

(a) The account number for each of the consumer's credit agreements;

(b) the account type; ${ }^{127}$

(c) the opening date, which is the date on which the loan or finance was granted or, in the case of a facility, the date on which the facility was last reviewed upwards; ${ }^{128}$

(d) the expiry date, which is the date on which the credit agreement should be paid off by, or in the case of certain facilities such as overdrafts, the date on which the review should take place;

(e) the registered bond amount in the case of a home loan; ${ }^{129}$

(f) where an asset has been financed, the goods description; ${ }^{130}$

(g) the credit limit, which is the amount available to a consumer under a credit facility; ${ }^{131}$

(h) the outstanding balance (including arrears); ${ }^{132}$

(i) the arrears amount; ${ }^{133}$

(j) the monthly instalment that the consumer is liable to pay each month towards the repayment of his debt, excluding fees and charges; ${ }^{134}$

reminder should grant the credit provider an additional five business days to respond. Da Silva et al (n 12) 16.

125 See Da Silva et al (n 12): Annexure E.

126 Da Silva et al (n 12) 34 et seq.

127 This information is important as it is required for the debt counsellor's statistical returns. Da Silva et al (n 12) 34.

128 This information is important as the debt counsellor need not investigate for possible reckless lending if the agreement or facility pre-dates 1 June 2007. Furthermore, the opening date is, in the case of vehicle or asset finance, used as part of the restructuring proposal. Da Silva et al (n 12) 35.

129 This is important as it assists the debt counsellor to recommend to the consumer that his obligations may be restructured without a debt review. Da Silva et al (n 12) 35.

130 This information assists the debt counsellor to make recommendations to the consumer regarding the suitability of the goods. Da Silva et al (n 12) 35.

131 This information assists the debt counsellor in establishing whether the consumer is abusing his credit facilities. Da Silva et al (n 12) 35.

132 This includes the capital amount, interest up to a specific date and charges, but excludes future interest and/or charges. Da Silva et al (n 12) 35.

133 Which include arrear interest and overdue payments. Da Silva et al (n 12) 35.

134 Where there is no contractual instalment, eg in the case of an overdraft, the instalment will be deemed to be the outstanding amount at the interest rate agreed upon over 12 months. 
(k) monthly charges that may be charged in terms of section 101;

(I) insurance or assurance premiums;

(m) method of payment of the monthly instalment; ${ }^{135}$

(n) the interest rate quoted as a percentage per annum on a net annual compounded monthly basis; ${ }^{136}$

(o) the type of interest rate which can either be fixed or variable; ${ }^{137}$

(p) the status of the account. ${ }^{138}$

As the above information is important for the debt counsellor to properly perform his duties in terms of the Act, it is suggested that the legislator should consider to regulate the type of information a credit provider is required to provide to the debt counsellor.

\subsubsection{Determination of over-indebtedness and recommendation by debt counsellor}

In terms of section 79(1) a consumer is considered to be over-indebted

if the preponderance of available information at the time a determination is made indicates that the particular consumer is or will be unable to satisfy ${ }^{139}$ in a timely manner all the obligations under all the credit agreements ${ }^{140}$ to which the consumer is a party.

In the case of credit card instalments the instalment includes the contractual monthly repayments on both the straight and budget facility account. Da Silva et al (n 12) 36 .

135 Especially in cases where the instalment is paid by way of stop order, it is important for the debt counsellor to take note of the method of payment as he must make arrangements for a reduced instalment. Da Silva et al (n 12) 36.

136 The debt counsellor will include interest on the agreement when preparing a proposal. Da Silva et al (n 12) 36.

137 This information is needed in order to ascertain whether the rate complies with reg 42(1) Table A. Da Silva et al (n 12) 37.

138 If summons has been issued and served the debt counsellor must exclude the agreement from debt review. S 86(2). The debt counsellor may however include a 'legal' agreement with the permission of the relevant credit provider. Da Silva et al (n 12) 37.

139 These words indicate that over-indebtedness does not only relate to existing inability to satisfy obligations but also to future inability. Scholtz et al (n 44) 11-5.

140 Over-indebtedness for the purposes of the Act only pertains to credit agreements to which the Act applies. Scholtz et al (n 44) 11-5. 
The determination in terms of section $79(1)^{141}$ is made by having regard to the consumer's -

(a) Financial means, prospects and obligations; ${ }^{142}$ and

(b) Probable propensity to satisfy in a timely manner all the obligations under all the credit agreements to which he is a party, as indicated by the consumer's history of debt repayment. ${ }^{143}$

'Financial means prospects and obligations' in respect of a consumer or prospective consumer includes:

(a) Income, or any right to receive income, regardless of the source, frequency or regularity of that income, other than income that the consumer or prospective consumer receives, has a right to receive or holds in trust for another person;

(b) The financial means, prospects and obligations of any other adult person within the consumer's immediate family or household, to the extent that the consumer, or prospective consumer and that other person customarily

(i) Share their respective financial means; and

(ii) Mutually bear their respective financial obligations; and

(c) If the consumer has or had a commercial purpose for applying for or entering into a particular credit agreement, the reasonably estimated revenue flow from that business purpose. ${ }^{144}$

It should be noted that the above is not a closed list. In the Panayiotts case, ${ }^{145}$ it was held that 'financial means' also includes assets and liabilities and

141 When making the determination the criteria set out in s 79(1) must be applied as they exist at the time the determination is being made. $S$ 79(2). The reason for this is that a consumer might have been able to afford the credit when he concluded the credit agreement, but became over-indebted thereafter because of other factors, eg retrenchment. Scholtz et al (n 44) 11-4. This situation should be distinguished from the situation where the concluding of the agreement actually caused the consumer to become over-indebted as the granting of credit in such a case amounts to reckless credit granting. Cf Scholtz et al (n 44) 11-4 and 11-5.

142 S 79(1)(a).

143 S 79(1)(b). Ito s 79(3)(a), when making a determination ito s 79(1) the value of any credit facility is the settlement value at the time of the determination under that facility. The value of any credit guarantee is the settlement value of the credit agreement it guarantees, if the guarantor has been called upon to honour that guarantee, or the settlement value of the credit agreement that it guarantees, discounted by a prescribed factor. $S$ 79(3)(b).

144 S 78(3)(a)-(c). 
'prospects' includes prospects of improving the consumer's financial position, such as increases and liquidating assets. In the case of credit agreements which involve goods as the subject matter of the agreement, the consumer's financial means and prospects must include the prospect of selling the goods in order to reduce the consumer's indebtedness.

In terms of regulation 24(6) the debt counsellor has 30 business days from the date of the application for debt review to make a determination in terms of section 86(6). ${ }^{146}$ It should be noted however, that the debt review can only be terminated in accordance with section 86(10) after a lapse of 60 business days after the date of application. When assessing the consumer's application for debt review the debt counsellor must make use of the information provided by the credit providers by referring to section 79. Furthermore, it must also consider the provisions of regulation 24(7):

(a) A consumer is over-indebted if his/her total monthly debt payments exceed the balance derived by deducting his/her minimum living expenses from his/her net income;

(b) Net income is calculated by deducting from the gross income, ${ }^{147}$ statutory deductions ${ }^{148}$ and other deductions that are made as a condition of employment; ${ }^{149}$

(c) Minimum living expenses ${ }^{150}$ are based upon a budget provided by the consumer, adjusted by the debt counsellor with reference to guidelines issued by the National Credit Regulator. ${ }^{151}$

145 Par 9, 10 and 77.

146 Ito the work stream guidelines the debt counsellor must make the determination within 10 days after the expiry of the 5 days grace given to a credit provider who has not responded to the request for financial information ito reg 24(3). Da Silva et al (n 12) 16.

147 See with regard to deductions for irregular income (eg overtime and commission) Da Silva et al (n 12) 23. Also see Da Silva et al (n 12) 24 iro the guidelines to be followed in respect of other income eg drawings of self-employed individuals, rent, maintenance, interest from investments etc.

148 These are deductions that an employer must make because of a court order or an act of parliament and include PAYE and SITE, UIF, emoluments attachment orders and garnishee orders. Salary stop orders where a service provider or employer has made an arrangement to deduct an amount from the employee's salary eg for services provided by the employer must however be excluded here. Da Silva et al (n 12) 24.

149 le deductions by an employer for services that the employee must subscribe to as a condition of employment eg pension, group life insurance and medical aid deductions. Da Silva et al (n 12) 24. 
As soon as the debt counsellor has completed the assessment, he must submit Form 17.2 to all the affected credit providers and all registered credit bureaux within five business days. ${ }^{152}$

If the debt counsellor determines that the consumer is not over-indebted, the debt counsellor must reject ${ }^{153}$ the consumer's application, even if he has concluded that a particular agreement was reckless at the time it was entered into. $^{154}$ In such a case the consumer can however still, with leave of the Magistrate's Court ${ }^{155}$ and within 20 business days after the debt counsellor has provided the consumer with a letter of rejection, ${ }^{156}$ apply directly to that court, in the prescribed manner and form, ${ }^{157}$ for an order in terms of section $86(7)$ (c). ${ }^{158}$ Section 86(9) read together with section 87 oblige the consumer to use the

150 Expenses consist of essential and non-essential expenses. Essential expenses are those that a consumer has little control over and which are necessary to conduct his daily life, eg rental, groceries, water and lights, etc. Da Silva et al (n 12) 27 et seq. With regard to financial services it should be noted that debt counsellors may not recommend any reductions in medical aid, insurance or assurance. If an amount seems to be exorbitant the debt counsellor should refer the consumer to a FAIS approved financial advisor. Da Silva et al (n 12) 28 et seq. Apart from having to make sure that an expense is essential the debt counsellor must also ascertain whether the expense is reasonable. Non-essential expenses are those expenses that are not absolutely necessary but are nevertheless an important part of the consumer's daily existence, eg domestic workers, garden service, entertainment, club memberships, etc. Allowance could be made for these expenses provided that it is reasonable in the circumstances. Luxurious items are those that the consumer do not need, eg multiple properties, M-Net, DSTV, holiday clubs, gambling, etc. Da Silva et al (n 12) 30.

151 To date, no such guidelines have been published by the NCR.

$152 \operatorname{Reg} 24(10)$.

153 Ito reg 25 the debt counsellor must then provide the debt counsellor with a letter of rejection containing certain prescribed information.

154 S 86(7)(a).

155 The exact procedure to follow when requesting leave is not prescribed in the Act or Regulations. However, reg 4(1) of the Debt Counselling Regulations published for comment in Gen Not 503 in GG 32229 of 15 May 2009 (hereafter Draft Regulations) prescribes the manner and form (Form $\mathrm{E}$ of the Annexure) of the application to obtain leave to institute proceedings ito $s$ 86(9).

156 Cf reg 26(1) read together with reg 25(5). The 20 days period may be extended by court if the consumer brings an application for such extension and is able to show good cause. Reg 26(2).

157 See reg 26(3) referring to Form 18 which is a standard form giving notice that application will be made for an order: (a) granting the applicant leave ito $s$ 86(9) to bring this application; (b) that the applicant is over-indebted ito s 79; (c) that certain agreements be declared reckless credit (if applicable) and (c) that the applicant's debt obligations be restructured.

158 S 86(9). 
application procedure ${ }^{159}$ to apply to the court, which must then conduct a hearing in terms of section $87 .^{160}$

If a determination is made that the consumer is not over-indebted but is nevertheless experiencing, or likely to experience difficulty satisfying in a timely manner all of his obligations under credit agreements, the debt counsellor may in terms of section $86(7)$ (b) recommend that the consumer and the respective credit providers voluntarily consider and agree on a debt arrangement plan. In this regard it should be noted that section 86(5) compels credit providers to "participate in good faith in the review and in any negotiations designed to result in responsible debt rearrangement". If a proposal in terms of section 86(7)(b) is accepted by the consumer and the credit providers concerned, the debt counsellor must record it in the form of an order and if it is consented to by the parties it must be filed as a consent order in terms of section $138 .^{161}$ If, however, the proposal is not accepted the debt counsellor must refer the matter to the Magistrate's Court with the recommendation. ${ }^{162}$

If the debt counsellor concludes that the consumer is indeed over-indebted the debt counsellor may issue a proposal recommending that the Magistrate's Court make an order that one or more of the credit agreements be declared to be reckless credit $^{163}$ and/or that one or more of the consumer's obligations be re-arranged. ${ }^{164}$

Rearrangement in terms of section 86(7)(c)(ii) can occur by -

159 Provided for in $r 55$ of the Magistrates' Courts Rules.

160 Cf Scholtz et al ( $n$ 44) 11-12. Reg 4 of the Draft Regulations gives a comprehensive explanation of the exact form and procedure to be followed when a consumer applies ito $\mathrm{s}$ 86(9). Ito reg 4(3) the consumer may apply for an order ito s 86(7)(c) in the form of Form $\mathrm{F}$ of the Annexure after the court has granted leave to the consumer to apply directly for the order. Reg 4(4) prescribes the information which the written statement of the consumer must contain and which must be annexed to the application. Credit providers are afforded the opportunity to oppose the application by filing a notice in the form of Form $G$ of the Annexure (see reg 4(5) and (6)). Reg 4(5) provides for the delivery of a notice iro the hearing of the application in Form $\mathrm{H}$ of the Annexure to each credit provider and reg 4(9) and (10) prescribe what such a hearing entails.

$161 \mathrm{~S} 86(8)(\mathrm{a})$.

162 S 86(8)(b).

163 S 86(7)(c)(i).

164 S 86(7)(c)(ii). 
(aa) extending the period of the agreement and reducing the amount of each payment due accordingly;

(bb) postponing during a specified period the dates on which payment are due under the agreement;

(cc) extending the period of the agreement and postponing during a specified period the dates on which payments are due under the agreement; or

(dd) recalculating the consumer's obligations because of contraventions of Part A or B of Chapter 5 , or Part A of Chapter $6 .^{165}$

Although section 86(7) does not provide for an order declaring the consumer over-indebted as envisaged in section 79 of the Act, it is obvious that such an order should be included as a consumer may only take part in the statutory debt review process if he is indeed over-indebted. ${ }^{166}$

\subsubsection{Procedure in referring matters to court}

Section 86 is silent on the procedure to be followed by the debt counsellor after he has 'issued' a proposal recommending that the Magistrate's Court make one of the orders as contemplated in section 86(7)(c)(i) and (ii). It is submitted that although section 86(8) does not refer to the procedure to be followed when a recommendation in terms of section $86(7)(c)$ is made, ${ }^{167}$ section 86(8)(b) should apply in such a case, and that the debt counsellor should refer the recommendation to the Magistrate's Court for a hearing under section $87 .{ }^{168}$ To remedy any uncertainty in this regard, it is submitted that $s$ 86(8) should be amended to also refer to s 86(7)(c).

165 These parts in ch 5 and 6 deal with unlawful agreements and provisions, disclosure, form and effect of credit agreements and with collection and repayment practices. Scholtz et al ( $n$ 44) 11-15 point out that a court may not reduce the interest rate which applies to an agreement in order to provide debt relief to the consumer. Boraine (n 26) 212 points out that although the court has the power to enforce a recommendation of the debt counsellor on the credit providers, the NCA does not sanction a statutory discharge of the debt in general.

166 Cf Da Silva et al (n 12) 48.

$167 \mathrm{~S} 86(8)$ only pertains to a recommendation ito subs (7)(b), while s 86(9) pertains to the procedure that could be initiated when the debt counsellor rejects the debt review application ito s 86(7)(a).

168 Cf Scholtz et al (n 44) 14-17; NCR: Founding Affidavit par 38. 
It is submitted that regulation 3 of the Draft Regulations addresses the issue pertaining to the procedure to be followed when referring a proposal to court in terms of section 86(7)(c). Regulation 3 provides that the debt counsellor must lodge the proposal in Form B which must be filed as soon as it has been delivered to the consumer and credit providers. Such proposal must be substantiated by a written statement which must contain the information set out in sub-regulation 2. The credit providers affected must be informed that they may oppose the proposal by filing a notice ${ }^{169}$ in the form of Form $C$ with the clerk of the court and delivering a copy thereof to the debt counsellor.

In terms of the work stream agreement the debt counsellor should however, not make any recommendations to court before he has prepared and submitted a debt restructuring proposal to the credit providers. ${ }^{170}$ If the proposal is accepted by the credit providers a consent order by the Magistrate's Court should be obtained. ${ }^{171}$ The Act, however, does not specifically provide for the obtaining of a consent order in such a situation and it is submitted that the legislator provide for this to clarify any uncertainty in this regard. ${ }^{172}$ It should be noted that regulation 2 of the Draft Regulations only provides for the confirming of consent

169 Cf Draft reg 3(4) which stipulates that the notice must be filed and delivered within 15 days after the proposal was served on the credit provider, that it must be substantiated by a written statement containing the credit provider's objections to the proposal and that it must be accompanied by a certified copy of the relevant agreement and relevant documentation intended to be used as evidence to substantiate the objections.

170 Cf Scholtz et al (n 44) 14-13. See Da Silva et al (n 12) 30 et seq regarding the guidelines to be followed when preparing a debt restructuring proposal. Ito the work stream guidelines the proposal must be sent within 25 days from the date of application and must be submitted to all credit providers who will then have 10 days to respond. Da Silva et al ( $\mathrm{n}$ 12) 17. If the debt counsellor fails to send a proposal within 25 days from the date of application the work stream agreed that credit providers should send a reminder whereafter the debt counsellor must submit his proposal within five days of this notice. If the credit providers have not responded within 10 days of submitting the proposal, it was agreed that the debt counsellor should send a reminder which gives the credit provider a further five days to respond. If the credit provider still fails to respond the debt counsellor must notify the credit provider that he will proceed as if the proposal had been declined. Da Silva et al (n 12) 17.

171 Da Silva et al (n 12) 17.

172 S 86(8)(a) only refers to the case where the debt counsellor makes a recommendation ito s 86(7)(b), ie where the debt counsellor found that the consumer is not over-indebted, but is nevertheless experiencing financial problems and recommends that the consumer and credit providers voluntarily consider and agree on debt re-arrangement. 
orders further to a recommendation in terms of section $86(7)(b)^{173}$ and does not deal with consent orders pertaining to debt restructuring proposals in terms of section $86(7)(c)^{174}$ of the Act. ${ }^{175}$ Unless this has been an oversight by the Minister, it would appear that a proposal in terms of section 86(7)(c) (that is, where the consumer was found to be over-indebted) is intended to be made directly to the court without it being necessary to first submit such a proposal to the credit providers for their response. ${ }^{176}$ Although this may expedite the debt counselling process it is submitted that, in light of the spirit of the Act, that all parties participate in good faith in the process of debt review and negotiations pertaining to the debt rearrangement, ${ }^{177}$ credit providers' responses should, rather be requested prior to the filing of a proposal to court. However, it should be noted that the Draft Regulations allow credit providers affected by the proposal to oppose a proposal that have been referred to court. ${ }^{178}$

If consensus cannot be reached between the consumer and the credit providers, the matter should, as explained above, be referred to the court. However, as pointed out above, the Act and Regulations are at present silent on the procedure for referral of a debt review matter to the Magistrate's Court. ${ }^{179}$ The following issues need to be clarified: ${ }^{180}$

\subsubsection{Should the consumer or the debt counsellor approach the court?}

Scholtz et al $^{181}$ submit that the consumer must approach the court. ${ }^{182}$ This viewpoint is, however, not without any problems as the consumer will probably have to instruct an attorney to bring the matter before the court which will bring

173 le where the debt counsellor concluded that the consumer was not over-indebted but is experiencing financial problems and recommended that the consumer and credit providers voluntarily consider and agree on a plan of debt re-arrangement.

174 le where the debt counsellor concluded that the consumer is indeed over-indebted and recommended that the court make the orders ito s 86(7)(c).

175 Draft reg 2 provides for the confirming of consent orders ito s 86(8)(a) of the NCA.

176 Cf reg 3 of the Draft Regulations.

177 Cf s 86(5)(b).

178 Draft reg 3(3).

179 Cf Scholtz et al (n 44) 14-16, Da Silva et al (n 12) 45; Stadler "Debt review applications"; Loots "Magistrate".

180 Scholtz et al (n 44) 14-16 et seq.

181 Scholtz et al (n 44) 14-16.

182 Cf also Da Silva et al (n 12) 47. 
about additional legal costs which the already over-indebted consumer will not always be able to afford. ${ }^{183}$

Regulation 3(1) of the Draft Regulations addresses the above-mentioned issue by providing for the lodging by the debt counsellor of the proposal in terms of section 86(7)(c) in Form B of the Annexure to the Draft Regulations. Such proposal must be filed with the clerk of the court after it has been delivered to the consumer and credit providers. It would also appear that the parties will not be entitled to recover costs on any basis from the other party at the eventual hearing as contemplated in terms of regulation 3(5). ${ }^{184}$ Furthermore, the parties will not be entitled to be represented by a legal practitioner unless the consent of all the parties has been obtained or the magistrate concludes that it is unreasonable to expect a party to deal with the application without legal representation. ${ }^{185}$

\subsubsection{The procedure to be employed in court ${ }^{186}$}

Section 87 provides that the Magistrate's Court must conduct a 'hearing'. However, neither the NCA, the Magistrates' Courts Act (MCA) nor the Magistrates' Courts Rules provide for a procedure in terms of which such a hearing should be conducted. ${ }^{187}$ Consequently, some Magistrate's Courts rely on their status as 'creatures of statute' and refuse to entertain debt rearrangement proceedings. ${ }^{188}$ It is submitted that draft regulation 4(10), if indeed applicable in respect of referrals in terms of section 86(7)(c), addresses the issue of the Act being silent on the procedure to be employed in court. ${ }^{189}$

183 Scholtz et al (n 44) 14-7 et seq.

184 Draft reg 4(10)(h).

185 See draft reg 4(10)(e). It should be noted that draft reg 4(10) prescribes what is permitted at the hearing contemplated in sub reg (8) (ie where the consumer applied ito s 86(9) because the debt counsellor rejected the consumer's application for debt review) and draft reg 4(5). It would however appear that this is a mistake and that the intention was to refer to reg 3(5). Draft reg 4(9) provides that the hearing "shall be administrative in nature and shall be conducted expeditiously in accordance with Section 33(1) of the Constitution of the Republic of South Africa". Draft reg 4(9) however explicitly refers to a hearing contemplated in sub reg (8).

186 Ibid. Also see Vessio (n 40) 239 n 85.

187 Scholtz et al (n 44) 11-28.

188 Scholtz et al (n 44) 11-29.

189 See the discussion in par 2.2.5.1 above. 
However, at present the motion (application) procedure in terms of rule 55 of the Magistrates' Court Rules are followed in practice. This entails the issuing and service of the notice of motion together with the founding and supporting affidavits. ${ }^{190}$ As relief is sought against the credit providers they will obviously be cited as respondents. ${ }^{191}$

The work stream agreed on the following minimum information in the founding affidavit of the consumer: ${ }^{192}$

(a) Particulars of the consumer ${ }^{193}$

A disclosure as to whether the consumer is married in or out of community of property should be included. ${ }^{194}$

(b) An allegation that the court has jurisdiction to entertain the matter

It should be noted that the NCA contains no provision which expressly deals with jurisdiction. According to the work stream guidelines it was the intention of the legislature that only the Magistrates' Courts should have jurisdiction to entertain debt review applications and to restructure credit agreements. ${ }^{195}$

The NCR suggested that the hearing of the recommendation by the Magistrate's Court in terms of section 87, is not one that takes place in terms of jurisdiction conferred on it by the MCA. It is submitted that a referral under section 87 is not an "action on or arising out of any credit agreement" and

190 Scholtz et al (n 44) 11-29; Da Silva et al (n 12) 46 et seq.

191 Da Silva et al (n 12) 49.

192 Cf Scholtz et al (n 44) 14-17 et seq.

193 le the full names, identity number (ID), residential and work address and occupation of the consumer.

194 As pointed out above, both spouses will be under debt review if the parties are married in community of property and only one application will be brought before court. If parties are married out of community of property only one partner will be applicant and under debt review. Da Silva et al (n 12) 51.

195 Cf S 86(7)(c), 86(8), 86(9) and 86(11) and 87 which refer to the Magistrate's Court and Da Silva et al (n 12) 51. Also see NCR: Founding Affidavit par 54-58. S 83 and 85 refer to 'court', therefore it would appear that either the Magistrate's Court or the High Court has jurisdiction to declare a consumer over-indebted or to make a declaration of reckless credit granting. Scholtz et al (n 44) 11-29. 
therefore section 29(1)(e) does not apply. ${ }^{196}$ Section 87 therefore applies and the debt counsellor may choose which Magistrate's Court he or she wants to approach. ${ }^{197}$

In terms of the work stream agreement, the person of the applicantconsumer ${ }^{198}$ rather than that of the respondent(s) (credit providers) should be taken into consideration when the issue of jurisdiction is to be determined. ${ }^{199}$ Even in the absence of such an agreement, it should be noted that section 28(1)(d) of the MCA states that the Magistrate's Court has jurisdiction to entertain matters where the whole cause of action arose within its area of jurisdiction. ${ }^{200}$ In this regard, it is argued that the application for debt review is the reason why the courts are approached, and not the disputes in terms of the individual agreements. Therefore, it is suggested that the Magistrate's Court in whose jurisdiction the debt review took place will have jurisdiction to entertain the matter. ${ }^{201}$

Credit providers participating in the work streams agreed not to oppose the monetary jurisdiction ${ }^{202}$ of the Magistrates' Courts. ${ }^{203}$ Even in the absence of such an agreement, it is however submitted that the court will still have jurisdiction to entertain a matter where the total outstanding amount on all credit

196 NCR: Founding Affidavit par 56.

197 It is submitted that there is no limitation on the debt counsellor's choice of court by $s$ 86(8)(b) as it merely refers to 'the Magistrate's Court', in the singular. NCR: Founding Affidavit par 57.

198 Cf also the NCR: Founding Affidavit par 58 and the position iro administration orders (s 74(1) of the MCA) ito which the person of the applicant-debtor is taken into consideration when jurisdiction is determined.

199 Nevertheless, credit providers have opposed applications contrary to what have been agreed by the work streams. Haupt, Roestoff and Erasmus (n 1) 117 et seq. As suggested by the NCR in the NCR: Founding Affidavit par 58 the argument that only the court in whose jurisdiction the credit providers carry on business will have jurisdiction is not justified as it will render any attempt to hold a hearing impossible. Furthermore, s 86(8)(b) and 87 do not place any limitation on the debt counsellor's choice of court, it simply refers to the 'Magistrate's Court'.

200 Da Silva et al (n 12) 51.

201 Ibid.

202 Which is currently determined by the Minister at R100 000 ito s 29(1)(g) of the MCA.

203 Da Silva et al (n 12) 51. Credit providers have nevertheless, contrary to the work stream agreement, opposed the jurisdiction of the court on this ground. Haupt, Roestoff and Erasmus (n 1) 119 et seq. 
agreements exceeds the current monetary limit, since section $86^{204}$ clearly states that the Magistrates' Courts should hear the matters. ${ }^{205}$ According to the work stream guidelines support for this argument is also to be found in section 29(1)(e) of the MCA, in terms of which actions based on or arising from credit agreements, as described in section 1 of the NCA, may be heard by Magistrates' Courts. It should be noted that no monetary jurisdiction has been placed on these matters. ${ }^{206}$

It is submitted that the definition of the term 'court' in regulation 1 of the Draft Regulations addresses the issue of jurisdiction:

'court' means magistrate court established in terms of the Magistrates' Courts Act ... having jurisdiction over a consumer by virtue of such consumer's residence or place of business or the residence or place of business of a debt counsellor irrespective of the monetary value involved.

(c) An allegation that the consumer is over-indebted

This allegation should be supported by proof of the consumer's income, the Form 17.1 and the certificates of balance which should be attached to the founding affidavit as an annexure. Details should be provided regarding which credit providers furnished balances and which failed to do so. A summary of the content of the certificate of balances should also be provided. ${ }^{207}$

(d) The total exposure of the consumer

A breakdown of the total exposure of the consumer must be provided and attached to enable the court to determine the reasonability of the original offer. An explanation regarding the process followed by the debt counsellor to establish that the consumer is over-indebted, must also be given. ${ }^{208}$

(e) The restructuring proposal

204 Cf S 86(7)(c), 86(8), 86(9) and (11).

205 Da Silva et al (n 12) 51. Also see NCR: Founding Affidavit par 59-60.

206 Da Silva et al (n 12) 51.

207 Da Silva et al (n 12) 52.

208 Ibid. 
A copy of the proposal, as provided to the credit providers, must be attached to the application. The affidavit must provide an explanation of how the restructuring proposal was drawn up with specific reference to the breakdown and re-apportionment of the debt and instalments as from the date of commencement until the date of the final payment. ${ }^{209}$

\section{(f) Details of which credit providers accepted or declined proposals}

The outstanding balance, term, interest rate and first payment date regarding the payments to be made to the credit providers who accepted the proposals, should be provided. Where proposals have been declined the reasons for refusal should be provided. ${ }^{210}$

(g) An explanation as to the specific circumstances of the consumer which makes the proposal reasonable.

The $\mathrm{NCR}^{211}$ suggests that the legislator has not intended that the application procedure in terms of rule 55 should be followed when a matter is referred to the Magistrate's Court in terms of section 86(8)(b). It is pointed out that section 86(8)(b), unlike section 86(9) which expressly refers to an application, uses the word 'refer'. Furthermore, the legislator intended a speedy and inexpensive procedure to be employed and not the cumbersome, costly and slow procedure in terms of rule 55. Accordingly, it is submitted that the Magistrate, in discharging his duties under section 87 ,

fulfils an administrative as opposed to a judicial role. He or she must consequently comply with the relevant provisions of the Constitution and the Promotion of Administrative Justice Act, 2000 ("PAJA"). That entails that the relevant magistrate must devise procedures which will facilitate a speedy, fair and expeditious hearing in terms of section 87 of the NCA. ${ }^{212}$

The main purpose of the Act, namely to protect consumers, obviously includes the purpose to avoid costly and cumbersome procedures and this factor should 
be taken into consideration when a procedure for referral of a matter to court as well as the hearing thereof is designed. Additionally, the issue of jurisdiction in respect of debt review matters should also be addressed in this light. ${ }^{213}$ It is submitted that the Draft Regulations succeed in this objective.

Regarding the powers bestowed on the Magistrate's Court in terms of section 87 , it should be noted that this section allows the court to only re-arrange the consumer's obligations. It does not make provision for a discharge of any of the consumer's debt. ${ }^{214}$ Consequently, it is submitted that debt review cannot be considered to be a genuine debt relief measure and that the legislator should consider providing for the possibility that the court could enforce a discharge of a part of the consumer's debt obligations.

\subsubsection{The issue of notification}

The Act and the Regulations do not specify how notification regarding the eventual hearing for debt rearrangement should be effected. ${ }^{215}$ As pointed out by Scholtz et al, ${ }^{216}$ the documents pertaining to the hearing should be regarded as court processes and should, in accordance with the audi alteram partem principle, be served on the affected parties. Apparently some credit providers insist on service by a sheriff. ${ }^{217}$ Scholtz et al ${ }^{218}$ submit that section 168 applies and that documents which have been either delivered to a credit provider or sent by registered mail to the credit provider's last known address will be regarded as having been properly served. The NCR submits that section 168 is not prescriptive. Accordingly the NCR is of the view that especially in light of the object of the NCA, to protect consumers, ${ }^{219}$ service by way of fax or email should also be allowed where the credit provider has consented to service in this manner in writing. 220

213 Cf Absa Bank Ltd v Myburgh Case no 31827/2007 (TPD) (unreported) par 43 and the discussion by Roestoff and Coetzee 2008 JCRDL 678-688.

214 Cf Boraine (n 26) 211 and 212.

215 Scholtz et al (n 44) 14-18.

216 Scholtz et al (n 44) 14-19.

217 Ibid.

218 Ibid.

219 Cf the Myburgh case par 43.

220 NCR: Founding Affidavit par 52.1.5. 
During the work streams, credit providers agreed that service by fax or e-mail (accompanied by an acknowledgement of receipt) on their debt review departments would be acceptable. ${ }^{221}$ Nonetheless, there have been instances where the Magistrates' Courts have refused to accept this form of service where credit providers have specifically consented thereto. ${ }^{222}$

As pointed out by the NCR, service by a sheriff would be inappropriate as it is a time-consuming and expensive process if service has to be effected to each credit provider of the consumer. Moreover, it should be kept in mind that the already over-indebted consumer would probably not be able to afford this manner of service. ${ }^{223}$

It is submitted that the definition of 'deliver' in regulation 1 of the Draft Regulations addresses the issue pertaining to notification of the hearing of the proposal $^{224}$ as it includes hand delivery, delivery by registered post, facsimile or email.

\subsubsection{The debt counselling payment distribution system}

Regulation 11 provides that a debt counsellor who receives payments on behalf of a consumer and/or distributes such funds to credit providers in terms of debt restructuring, must comply with the required legislation and must advise the NCR of its receiving and/or distributing such funds. However, the collection and distribution of monthly payments following on debt restructuring are currently dealt with by so-called 'Payment Distribution Agents' (PDAs) which are at present not regulated in the Act or the Regulations. Although the effectiveness of this system obviously depends to a great extent on trust and effective

221 Da Silva et al (n 12) 53.

222 NCR: Founding Affidavit par 52.1.5.

223 NCR: Founding Affidavit par 52.1. Cf also Scholtz et al (n 44) 14-18.

224 See reg 3(5) of the Draft Regulations which provides for the delivery of a notice iro the hearing of the proposal in accordance with Form D after expiry of 15 days after the proposal was served on the credit providers. Delivery of such notice to the credit providers should however be effected at least 15 days before the date of the hearing. 
communication between all stakeholders, ${ }^{225}$ it is submitted that the legislator should regulate issues such as the nomination and appointment of PDAs by the debt counsellor and court. However, it is submitted that the issue of registration and monitoring of PDAs are addressed satisfactorily by regulation 5 of the Draft Regulations.

\subsubsection{Termination of debt review}

Section 86(10) provides that -

if a consumer is in default under a credit agreement that is being reviewed in terms of this section, the credit provider in respect of that credit agreement may give notice to terminate the review in the prescribed manner ${ }^{226}$ to

(a) the consumer;

(b) the debt counsellor; and

(c) the National Credit Regulator,

at any time at least 60 business days after the date on which the consumer applied for the debt review.

The effect of this provision is that the debt counsellor is given 60 business days to complete the debt review process in terms of section $86 .{ }^{227}$ After 60 days the credit provider can proceed with the enforcement of the specific ${ }^{228}$ credit agreement and a section 129(1)(a) notice need not precede litigation. ${ }^{229}$ It should however be noted that the Magistrate's Court hearing the matter may

225 le the consumer, debt counsellor, credit providers and the PDA. See research report by Heymans 2009 www.ncr.org.za/; Pienaar "Payment distribution agent".

226 Currently the Regulations do not prescribe anything wrt the form of the notice. Boraine and Renke 2008 De Jure $4 \mathrm{n}$ 19. Cf also Scholtz et al (n 44) for an example of what would in their view suffice as a notice to terminate. According to the work stream agreement notice must be sent to the consumer and debt counsellor by fax, e-mail or mail. Da Silva et al (n 12) 56. It is submitted that $s 65$ of the NCA should apply and that the consumer may choose the manner of delivery from the options of either personal delivery, fax, e-mail or printable web page.

227 Boraine and Renke 2008 De Jure $4 \mathrm{n} 21$.

228 Termination thus do not effect the other credit agreements in the review. Da Silva et al ( $\mathrm{n}$ 12) 56. Scholtz et al ( $n$ 44) point out however that the wording of $s 86(10)$ is unclear as it is capable of being interpreted to mean that a single credit provider may terminate a debt review despite the fact that other credit providers want to continue with negotiations and finalise the matter.

229 Scholtz et al (n 44) 12-18. 
order that the debt review resume on any conditions that the court consider to be just in the circumstances. ${ }^{230}$

In the work streams, it was agreed that credit providers would first issue a notice that they will terminate within ten days. ${ }^{231}$ It should however be noted that a credit provider may terminate a debt review even if the consumer has been making payments and a proposal has been submitted to credit providers. A debt counsellor must proceed to obtain a consent order or refer the matter to court if the matter cannot be resolved through negotiations. ${ }^{232}$

Termination of the debt review process can also take place after rejection of a debt review application by the debt counsellor in terms of section $86(7)(a){ }^{233}$ The consumer or the debt counsellor may also withdraw from the process. The process for withdrawal is however not regulated by the Act or Regulations. In terms of the work stream agreement, if the consumer wishes to withdraw, written notice must be provided to the debt counsellor, including the consumer's reasons for withdrawing. A debt counsellor may also withdraw from the debt review if a consumer is dishonest or is not co-operating. Thereby the consumer is for the time being dispossessed of his right to be afforded debt relief in terms of the Act. In terms of the work stream agreement, the debt counsellor is in cases of voluntary withdrawal and withdrawal by the debt counsellor, obliged to inform the consumer that legal action may be taken in respect of credit agreements that are in default. The consumer must also be informed that his or her credit record will, for a period of six months show that he or she has voluntarily withdrawn from the debt review process or that his or her review has been terminated by the debt counsellor, as the case may be. The consumer must furthermore, be informed that he or she is still liable for the debt counselling fees to date and that he is entitled to re-apply for debt counselling. In terms of the work stream agreement credit providers must be notified of any 
voluntary withdrawal within five days on a Form $17.4 .^{234}$ In terms of the agreement, the debt counsellor may not refuse to withdraw because the consumer has not paid any of his fees. ${ }^{235}$ In the case of withdrawal by the debt counsellor, the consumer must be given ten business days to respond to the debt counsellor, failing which, he may then withdraw. ${ }^{236}$

\subsubsection{After care and clearance certificate}

The debt counsellor must monitor payments by the consumer for the full period of the debt review. ${ }^{237}$ It is suggested that a follow-up consultation should take place at least once a year. Credit providers should be notified of any changes to the consumer's circumstances on Form 17.3. ${ }^{238}$

When all the debt obligations under every credit agreement that was subject to the debt rearrangement order or agreement has been repaid the debt counsellor $^{239}$ must issue a clearance certificate in Form 19. ${ }^{240}$ This would mean that a consumer, who for example, has a home loan agreement with a repayment period of 30 years as one of his or her credit agreements under debt rearrangement, would only be able to be relieved from the consequences of debt review after a period of at least 30 years. In order to provide for a proper and genuine debt relief measure, it is submitted that the legislator should consider the introduction of a new provision in terms of which the court, on application by the consumer, may relieve the consumer of the disabilities resulting from debt rearrangement at an earlier stage.

234 Cf Da Silva et al (n 12): Annexure D.

235 Da Silva et al (n 12) 19.

236 Obviously consumers may also change debt counsellors at any time or the debt counsellor may transfer a consumer to another debt counsellor. The party initiating the transfer should notify the other party. Da Silva et al (n 12) 20.

237 Da Silva et al (n 12) 20.

238 Da Silva et al (n 12): Annexure F.

239 Not the court. Scholtz et al (n 44) 14-14.

240 Reg 27 and see s 71 which provides for the removal of a record of debt adjustment or judgment and Scholtz et al (n 44) 11-27 et seq. 


\subsubsection{Effect of debt review or debt rearrangement}

Section 88 deals with the consequences of debt review or debt rearrangement for the consumers and their credit providers. A consumer who has applied for debt review or who has alleged in court that he or she is over-indebted, may not incur any further charges under a credit facility or enter into any further credit agreement (other than a consolidation agreement) until one of the following events has occurred: ${ }^{241}$

(a) The debt counsellor rejects the application and the prescribed time period for direct filing in terms of section 86(9) has expired without the consumer having so applied;

(b) the court has determined that the consumer is not over-indebted, or has rejected a debt counsellor's proposal or the consumer's application; or

(c) a court having made an order or the consumer and credit providers having made an agreement re-arranging the consumer's obligation, all the consumer's obligations under the credit agreement as re-arranged are fulfilled, unless the consumer fulfilled the obligations by way of a consolidation agreement. $^{242}$

A credit provider who enters into a credit agreement in contravention of the prohibition in section 88(1), runs the risk of such an agreement being declared to be reckless credit, whether the circumstances set out in section 80 apply or not. ${ }^{243}$ For the consumer, severe consequences also follow if he or she applies $^{244}$ for or enters into a credit agreement contrary to section 88. In such a case, section 88(5), in effect, divests the consumer of his right to be afforded debt relief under the Act as it provides that the provisions of the Act relating to

$241 \mathrm{~S} 88(1)$.

242 In case of a consolidation agreement the effect of $s$ 88(1) continues to apply until the consumer fulfils all the obligations under the consolidation agreement, unless the consumer again fulfilled it by way of a consolidation agreement. $S$ 88(2).

$243 \mathrm{~S} \mathrm{88(4).} \mathrm{A} \mathrm{new} \mathrm{category} \mathrm{of} \mathrm{reckless} \mathrm{credit} \mathrm{is} \mathrm{thus} \mathrm{created} \mathrm{in} \mathrm{addition} \mathrm{to} \mathrm{those} \mathrm{mentioned} \mathrm{in}$ s 80 and the consequences of reckless credit would therefore apply. Scholtz et al (n 44) 11-19.

244 The sanction provided for in $\mathrm{s} 88(5)$ therefore not only applies to the situation where the consumer enters into a credit agreement. Scholtz et al (n 44) 11-19. 
over-indebtedness and reckless credit contained in Part D of Chapter 4 of the Act will never apply to such an agreement. ${ }^{245}$

Section 88(3) provides that a credit provider who receives notice of court proceedings in terms of section $83^{246}$ or $85^{247}$ or a notice ${ }^{248}$ that a consumer has applied for debt review may not exercise or enforce, by litigation or other judicial process, any right or security under that credit agreement until the following events have taken place:

(b) the consumer is in default under the credit agreement; and

(c) one of the following has occurred:

(i) An event contemplated in subsection (1)(a) through (c); ${ }^{249}$ or

(ii) the consumer defaults on any obligation in terms of a rearrangement agreed between the consumer and credit providers, or ordered by a court or the Tribunal.

It is important to note that the effect of section 88(3) is explicitly made subject to section 86(10). ${ }^{250}$ Consequently, it is submitted that a credit provider would be entitled to enforce a credit agreement where the consumer is in default, and the events contemplated in section 88(1) have not occurred, as long as the credit provider has proceeded to terminate the debt review process in terms of section 86(10). In the case of First Rand Bank $v$ Smith $^{251}$ the court however interpreted and applied section 88(3) to the facts of the case, without taking cognisance of the possible application of section $86(10){ }^{252}$

245 Cf Scholtz et al (n 44) 11-19.

246 S 83 provides that the court may declare that a credit agreement is reckless and may suspend it as reckless credit.

247 Ito s 85 the court may declare and relieve over-indebtedness.

248 Ito $s$ 86(4)(b)(i).

249 le s 88(1)(a)-(c).

250 And also s 86(9).

251 Case no 24205/08 (WLD) (unreported).

252 See the case discussion by Roestoff 2009 Obiter. 


\section{Concluding remarks and proposed amendments to legislation}

As pointed out above, ${ }^{253}$ legislative gaps are without doubt one of the major obstacles in the debt counselling process. Although the work stream guidelines are to be welcomed because they attempt to find a solution for these problems, the situation is still not desirable. Many credit providers and debt counsellors did not form part of the work stream processes and therefore cannot be bound by these agreements. ${ }^{254}$ The NCR's application to the High Court for a declaratory order may shed some light on the problems currently experienced, however, it is submitted that the best solution is, for the legislator to address these shortcomings in order to bring about a proper and effective debt review process. ${ }^{255}$ By also taking the Draft Regulations into consideration, it is submitted that the following issues should be addressed by the legislator: ${ }^{256}$

3.1 A review of the requirements pertaining to the education, experience and competence of debt counsellors. ${ }^{257}$

It is suggested that regulation 10 be amended as follows: ${ }^{258}$

10. A person who applies for registration as a debt counsellor must meet the following further requirements-

(a) Education:

(i) a Grade 12 certificate or equivalent Level 4 qualification issued by the South African Qualifications Authority; and

(ii) successful completion of a debt counselling course approved by the National Credit Regulator and provided by an institution approved by the National Credit Regulator.

253 Par 2.1.

254 Scholtz et al (n 44) 14-19.

255 Ibid.

256 Proposed amendments to provisions of the NCA and regulations will be indicated by underlining the relevant insertions and substitutions.

257 See the discussion in par 2.2.2 above.

258 It is suggested that the current sub-regulation 10(b)(i)(ff) be deleted as its application is to wide and allows almost any working experience to be sufficient ito this section. 
(b) Experience and Competence:

(i) a minimum of five years working experience in any of the following fields-

(aa) consumer protection, complaints resolution or consumer advisory service;

(bb) legal or para-legal services;

(cc) accounting or financial services;

(dd) education or training of individuals;

(ee) counselling of individuals

provided that if a person who applies for registration in terms of this regulation does not comply with the criteria pertaining to experience as contemplated in sub-regulation (b)(i) of this regulation, such a person will still be able to apply for registration as a debt counsellor if he/she possesses a tertiary qualification in either the field of law or economic and management sciences.

(ii) demonstrated ability to:

(aa) manage his/her own finances at the time of applying for registration; and

(bb) provide counselling or transfer skills.

3.2 Clarity as to whether the High Court or the Magistrate's Court has the powers in terms of section 85 if it is alleged in High Court that a consumer is over-indebted. ${ }^{259}$ With reference to the Panayiotts case ${ }^{260}$ it is suggested that section 85 be amended as follows:

85. Despite any provision of law or agreement to the contrary, in any court proceedings in which a credit agreement is being considered, if it is alleged that the consumer under a credit agreement is over-indebted, the court in which the allegation of over-indebtedness has been made may- 
(a) refer the matter directly to a debt counsellor with a request that the debt counsellor evaluate the consumer's circumstances and make a recommendation to the court in which the allegation of over-indebtedness has been made in terms of section 86(7); or

(b) declare that the consumer is over-indebted, as determined in accordance with this Part, and make an order contemplated in section 87 to relieve the consumer's overindebtedness.

3.3 A new Form 16 which would assist debt counsellors to better inform their clients of the consequences of debt review. ${ }^{261}$

3.4 The regulation of the fees that may be recovered by debt counsellors and the amendment of section 86(3) to provide for the possibility that credit providers could also bear some of the debt counselling costs. ${ }^{262}$

In this regard it is suggested that the recommended cost and fee structure drafted by $\mathrm{DCSA}^{263}$ should be incorporated in the regulations to the NCA. Additionally, it is suggested that credit providers be made responsible for the PDA fees. ${ }^{264}$ The current section $86(3)$ should be substituted with the following provision:

(3)(a) A debt counsellor may require the consumer and the consumer's credit providers to only pay the prescribed fees pertaining to the process of debt review.

(b) A registered payment distribution agency may, in respect of services rendered by such agency in terms of a court order, recover from the credit provider a commission prescribed in the regulations of all the amounts paid to such a credit provider by deducting such commission from the amount paid to the credit provider.

261 See the discussion in par 2.2.2 above and Haupt, Roestoff and Erasmus (n 1) 103 et seq for the proposed improved Form 16.

262 See the discussion in par 2.2.2 above.

263 See the discussion in par 2.2.2 above.

264 Cf s 65J(10) of the MCA iro emoluments attachment orders. 
3.5 The amendment of section 86(2) by substituting the words 'section 129' with 'section 130'. ${ }^{265}$

3.6 The regulation of the type of information ${ }^{266}$ a credit provider is required to provide to the debt counsellor pursuant to a request in terms of regulation 24(3) for verification of information provided by the consumer. ${ }^{267}$

(aa) It is suggested that section $86(4)$ be amended by adding a new subsection (c):

(c) verify the information provided in the application in terms of subsection (1), in the prescribed manner and form.

(bb) It is furthermore suggested that regulation 24(3) be substituted with the following provision:

(3) In verifying the information provided in terms of sub-regulation

(1) above, the debt counsellor-

(a) may use any method of verification; and

(b) must-

(i) request documentary proof from the consumer; and

(ii) contact the relevant credit provider by delivering Form 17.1 as contemplated in sub-regulation (2) who must then complete and submit Form $16.2^{268}$ to the debt counsellor within five business days of such verification being requested.

3.7 Amendment of section 86(8) to include the instance where a recommendation is made by the debt counsellor in terms of section $86(7)$ (c) and to specifically provide for the obtaining of a consent order

265 Ibid.

266 The 'Certificate of Balance'.

267 See the discussion in par 2.2.3 above.

268 It is suggested that Form 16.2 should be in the form proposed in the work stream guidelines. Da Silva et al (n 12): Annexure E. 
when a debt restructuring proposal in terms of section $86(7)(c)$ is accepted by all credit providers. ${ }^{269}$

3.8 Clarity on the procedure to be followed in court when a matter is 'referred' to the Magistrate's Court because the consumer and credit providers could not reach consensus on a debt restructuring proposal. Related issues, such as the jurisdiction of the court to entertain debt review matters, the person who should approach the court and the issue of notification regarding the eventual hearing for debt rearrangement, should also be clarified. $^{270}$

3.9 Amendment of sections 86(7)(c) and 87 to provide for the possibility that the court could enforce a discharge of a part of the consumer's debt obligations. $^{271}$

(aa) Amendment of section 86(7)(c):

(c) the consumer is over-indebted, the debt counsellor may issue a proposal recommending that the Magistrate's Court declares that the consumer is over-indebted and make one or all of the following orders-

(i) that one or more of the consumer's credit agreements be declared to be reckless credit, if the debt counsellor has concluded that those agreements appear to be reckless; and

(ii) that one or more of the consumers' obligations be re-arranged by-

(aa) extending the period of the agreement and reducing the amount of each payment due accordingly;

(bb) postponing during a specified period the dates on which payments are due under the agreement;

269 See the discussion in par 2.2.5 above.

270 It is submitted that the Draft Regulations iro this issue should be implemented. See the discussion in par 2.2.5 above.

271 Ibid. 
(cc) extending the period of the agreement and postponing during a specified period the dates on which payments are due under the agreement; or

(dd) recalculating the consumer's obligations because of contraventions of Part A or B of Chapter 5, or Part A of Chapter 6.

(iii) that any part of one or more of the consumer's obligations be discharged and that such obligations, subject to section $88 \mathrm{~A}^{272}$ ceases to be binding on the consumer.

(bb) Amendment of section 87(1):

87(1) If a debt counsellor makes a proposal to the Magistrate's Court in terms of section 86(7)(c) and 86(8)(b), or a consumer applies to the Magistrate's Court in terms of section 86(9), the Magistrate's Court must conduct a hearing in the prescribed manner $^{273}$ and, having regard to the proposal and information before it and the consumer's financial means, prospects and obligations may-

(a) reject the recommendation or application as the case may be; or

(b) declare that the consumer is over-indebted and make-

(i) an order declaring any credit agreement to be reckless, and an order contemplated in section 83(2) or (3), if the Magistrate's Court concludes that the agreement is reckless;

(ii) an order re-arranging the consumer's obligations in any manner contemplated in section 86(7)(c)(ii);

(iii) an order contemplated in section 86(7)(c)(iii); or

(iv) an order appointing a payment distribution agent, registered by the National Credit Regulator, and which 
will be responsible for the collection and distribution of payments received from the consumer after a debt restructuring order or agreement; or

(v) all the orders contemplated in subparagraph (i), (ii), (iii) and (iv) of subsection (1)(b).

3.10 With regard to the debt counselling payment distribution system, issues such as the appointment of PDAs by the court $^{274}$ as well as the registration and monitoring of PDAs by the NCR, should be addressed. ${ }^{275}$

3.11 Regulation of the process to be followed when a consumer or the debt counsellor withdraws from the debt review process. ${ }^{276}$

A new section $86 \mathrm{~A}$ is suggested:

\section{Withdrawal from the debt review process}

86A. (1) A consumer may voluntarily withdraw an application in terms of section 86 at any time before an order of court as contemplated in section 86(8) has been granted, by delivering a written notice to the debt counsellor that the consumer is withdrawing the application, including the reasons for such withdrawal.

(2) Within five business days after receiving a notice as contemplated in subsection (1), the debt counsellor must notify all credit providers that are listed in the application in terms of section 86 and every registered credit bureau in the prescribed manner and form ${ }^{277}$ that the consumer has voluntarily withdrawn the application in terms of section 86 .

(3) A debt counsellor may withdraw an application in terms of section 86 if the debt counsellor is of the opinion that the consumer is dishonest or is not co-operating with regard to the application in terms of section 86. 
(4) Within five business days after a withdrawal as contemplated in subsection (3), the debt counsellor must notify the consumer and all credit providers listed in the application in terms of section 86 as well as every registered credit bureau in the prescribed manner and form ${ }^{278}$ of the withdrawal.

(5) A notice of withdrawal contemplated in subsection (4) may only be delivered after at least 10 business days have elapsed since the debt counsellor delivered a written notice to the consumer of the debt counsellor's intention to withdraw the application, including the debt counsellor's reasons for such intended withdrawal, and the consumer has failed to respond to such a notice.

(6) If a consumer or the debt counsellor withdraws an application for debt review as contemplated in terms of this section, the debt counsellor must inform the consumer that-

(a) any of the consumer's credit providers may approach the court for an order to enforce a credit agreement in respect of which the consumer is in default;

(b) the consumer's credit record will, for a period of six months, reflect that the consumer has voluntarily withdrawn the application or that the debt counsellor has withdrawn the application, as the case may be;

(c) the consumer is liable for all debt counselling fees prescribed in terms of the Act and which are due up to the date of withdrawal;

(d) the consumer is entitled to re-apply for debt review in terms of section 86 .

3.12 The introduction of a new provision in terms of which the court, on application by the consumer, may relieve the consumer from the disabilities resulting from debt rearrangement: ${ }^{279}$

(aa) A new section 88A is suggested:

Magistrate's Court may relieve consumer of disabilities resulting from debt rearrangement 
88A. A consumer whose debts have been rearranged in terms of Part D of this Chapter may apply to the Magistrate's Court of the district in which the consumer resides or carries on business or is employed at any time for an order relieving the consumer of every disability resulting from debt rearrangement, and the court may grant such an order if it is satisfied-

(a) that the consumer has paid all arrear instalments of all credit agreements which are subject to the debt rearrangement order or agreement; and

(b) that the consumer has reaffirmed any obligations that have been discharged as contemplated in section 86(7)(c)(iii), to be binding on the consumer again; and

(c) that the consumer is able to resume repayment of all obligations in terms of the original credit agreements concluded between the consumer and relevant credit providers; and

(d) that the court is of the opinion that the consumer can no longer be regarded to be over-indebted as contemplated in section 79 .

(bb) It is suggested that regulation 27 should apply in instances where a consumer has fully satisfied all debt obligations in accordance with the rearrangement agreement or order as contemplated in the proposed amended section 86(8) read together with the proposed amended section 87(1). If a consumer wishes to be relieved from the disabilities resulting from debt rearrangement at an earlier stage he or she needs to comply with the proposed section 88A.

(cc) It is suggested that section 71(4) and (5) be amended to provide as follows:

(4) A consumer to whom a clearance certificate is issued in terms of this section or in whose favour an order contemplated in section 88A has been granted, may file a certified copy of that certificate or order with the national register established in terms of section 69 or any credit bureau.

(5) Upon receiving a copy of a clearance certificate or court order, a credit bureau, or the national credit register, must expunge from its records-

(a) the fact that the consumer was subject to the relevant debt rearrangement order or agreement;

(b) any information relating to any default by the consumer that may have-

(i) precipitated the debt rearrangement; or 
(ii) been considered in making the debtrearrangement order or agreement; and

(c) any record that a particular credit agreement was subject to the relevant debt rearrangement order or agreement.

(dd) Paragraph (d) should be added to section 88(1):

(d) a court have made an order as contemplated in section 88A.

(ee) Section 88(3)(b)(i) should be amended as follows:

(i) An event contemplated in subsection (1)(a) through (d); or

Ultimately, the effectiveness of the Act's provisions to provide relief to the overindebted consumer depends on the co-operation of the different role players and compliance with the spirit of the $\mathrm{Act}^{280}$ elucidated in section 86(5)(b) as follows:

[A] consumer who applies to a debt counsellor, and each credit provider ... must participate in good faith in the review and any negotiations designed to result in responsible debt rearrangement.

During these negotiations the purpose of the Act, namely to protect consumers should constantly be kept in mind. Credit providers will have to change their attitudes and appreciate the fact that they will have to take greater responsibility for the negative consequences of credit granting. In this regard the following statement of the court in the Prochaska case, is important:

It is abundantly clear, in my view, that the Act has introduced innovative mechanisms and concepts directed more for the protection and in the interests of credit consumers than that of credit providers. ${ }^{281}$

Although the NCA aims to resolve consumer indebtedness by providing for debt review and debt restructuring, it also aims to prevent over-indebtedness by inter 
alia incorporating consumer education in the mandate of the NCR. ${ }^{282}$ Statistics ${ }^{283}$ indicating that nearly half of credit active South African consumers have bad credit records and more than 42000 consumers are currently undergoing debt counselling signify that still more should be done to prevent over-indebtedness and to reduce the need for consumers to resort to the debt relief mechanisms of the Act. It must therefore be clear that there is a definite need for consumer education at both the adult and school level. ${ }^{284}$

282 Cf s 3(e)(i), (g) and (i) read together with s 16(1)(a); Roestoff and Renke 2005 JCRDL 115-121; Renke, Roestoff and Bekink 2006 IIR 91-107; Kelly-Louw (n 8) 225.

283 See par 1 above.

284 It is interesting to note that already in 1995 the South African Consumer Credit Association recommended that financial education be included in the South African school curriculum. See SALC Project 74 118; Roestoff and Renke 2005 IIR 102; Roestoff and Renke 2003 Obiter 8; Kelly-Louw (n 8) 211; Richards "Debt counsellor". 


\section{Bibliography}

Boraine "Reform"

Boraine $A$ "The reform of administration orders within a new consumer credit framework" in Kelly-Louw M, Nehf JP and Rott P (eds) The Future of Consumer Credit Regulation Creative Approaches to Emerging Problems (Ashgate Aldershot 2008) 187-216

Boraine and Renke 2007 De Jure

Boraine $A$ and Renke S "Some practical and comparative aspects of the cancellation of instalment agreements in terms of the National Credit Act 34 of 2005" (part 1) 2007 De Jure 222-235

Boraine and Renke 2008 De Jure

Boraine A and Renke S "Some practical and comparative aspects of the cancellation of instalment agreements in terms of the National Credit Act 34 of 2005" (part 2) 2008 De Jure 1-15

Du Plessis 2007 JJS

Du Plessis MA "The National Credit Act: Debt counselling may prove to be a risky enterprise" 2007 Journal for Juridical Science 76-94

Du Preez Saturday Star

Du Preez L 'Merits of new debt counselling process yet to be proved' Saturday Star 6 October 20074

Eastonberry "Attorney"

Eastonberry R "The attorney for the NCA credit provider" (Unpublished paper delivered at a Conference on Debt Enforcement 16-17 March 2009 Midrand)

\section{Gerretsen Saturday Weekend Argus}

Gerretsen B 'Debt counselling spikes as hikes hit consumers' Saturday Weekend Argus 21 June 200812 


\section{Gillingham Sunday Times 21}

Gillingham A 'It's time to ring up the debt counsellor' Sunday Times 1 June 200821

Haupt, Roestoff and Erasmus Debt Counselling Process

Haupt F, Roestoff M and Erasmus M The Debt Counselling Process:

Challenges to Consumers and the Credit Industry in General (Report submitted by the University of Pretoria Law Clinic to the National Credit Regulator April 2009)

Jackson Mail and Guardian

Jackson D 'Debt counselling: no quick fix' Mail and Guardian 5 June 2008 42

Kelly-Louw 2008 SAMercLJ

Kelly-Louw $\mathrm{M}$ "The prevention and alleviation of consumer overindebtedness" 2008 SA Mercantile Law Journal 200-226

Khanyile Star

Khanyile S 'Debt counselling is 'misunderstood" Star 12 March 200820

Loots "Magistrate"

Loots C "The magistrate and the application of the NCA in debt enforcement" (Unpublished paper delivered at a Conference on Debt Enforcement 16-17 March 2009 Midrand)

Naidu Sunday Independent

Naidu E 'Now even debt counsellors are feeling the pinch' Sunday Independent 1 June 20081

NCR: Founding affidavit Founding affidavit to the National Credit Regulator's application for a declaratory order in terms of section 16 of the National Credit Act National Credit Regulator v Nedbank Ltd and others (Unreported case no 19638/08 TPD) 
Otto "Credit provider"

Otto C "The credit provider and NCA debt enforcement" (Unpublished paper delivered at a Conference on Debt Enforcement 16-17 March 2009 Midrand)

Otto National Credit Act explained

Otto JM The National Credit Act Explained (LexisNexis Butterworths Durban 2006)

Pienaar "Payment distribution agent"

Pienaar $\mathrm{H}$ "The role and function of the payment distribution agent"

(Unpublished paper delivered at a Conference on Debt Enforcement 16-17 March 2009 Midrand)

Renke, Roestoff and Bekink 2006 IIR

Renke S, Roestoff M and Bekink B "New legislative measures in South Africa aimed at combating over-indebtedness - are the new proposals sufficient under the constitution and law in general? 2006 International Insolvency Review 91-107

Renke, Roestoff and Haupt 2007 Obiter

Renke S, Roestoff M and Haupt F "The National Credit Act: New parameters for the granting of credit in South Africa" 2007 Obiter 229-270

Richards "Debt counsellor"

Richards T "The debt counsellor and debt restructuring" (Unpublished paper delivered at a Conference on Debt Enforcement 16-17 March 2009 Midrand)

Roestoff 2009 Obiter

Roestoff $M$ "Enforcement of a credit agreement where the consumer has applied for debt review in terms of the National Credit Act 34 of 2005" (accepted for publication in 2009 (2) Obiter)

Roestoff and Coetzee 2008 JCRDL

Roestoff $\mathrm{M}$ and Coetzee $\mathrm{H}$ "Consent to jurisdiction - unlawful provision in a $301 / 360$ 
credit agreement - is the jurisdiction of a court ousted thereby?" 2008 Journal of Contemporary Roman-Dutch Law 678-688

Roestoff and Renke 2003 Obiter

Roestoff $M$ and Renke S "Solving the problem of over-indebtedness:

International guidelines" 2003 Obiter 1-26

Roestoff and Renke 2005 IIR

Roestoff M and Renke S "A fresh start for individual debtors: The role of

South African insolvency and consumer protection legislation" 2005

International Insolvency Review 93-109

Roestoff and Renke 2005 JCRDL

Roestoff M and Renke S "The Consumer Credit Bill - a solution to overindebtedness?" 2005 Journal of Contemporary Roman-Dutch Law 115-121

Roestoff and Renke 2006 Obiter

Roestoff $M$ and Renke S "Debt relief for consumers - the interaction between insolvency and consumer protection legislation" (part 2) 2006

Obiter 98-110

SALC Project 74

South African Law Commission Project 74 Debt Collecting (1995)

Scholtz et al Credit Act

Scholtz JW et al Guide to the National Credit Act (LexisNexis Butterworths Durban 2008)

Stadler "Debt review applications"

Stadler S "Debt review applications to the Magistrate's Court" (Unpublished paper delivered at a Conference on Debt Enforcement 16-17 March 2009 Midrand)

Stewart Daily Dispatch

Stewart T 'Millions in debt trap overwhelm counsellors' Daily Dispatch 21 August 200811 
Stoop 2008 De Jure

Stoop PN "Kritiese evaluasie van die toepassingsveld van die 'National Credit Act"' 2008 De Jure 352-370

Van Heerden and Otto 2007 JSAL

Van Heerden CM and Otto JM "Debt enforcement in terms of the National Credit Act 34 of 2005" 2007 Journal of South African Law 655-684

Van Loggerenberg, Dicker and Malan 2008 De Rebus

Van Loggerenberg D, Dicker $L$ and Malan J "Aspects of debt enforcement under the National Credit Act" 2008 De Rebus 40-44

Van Wyk "F(r)iction"

Van Wyk D "F(r)iction in debt enforcement" (Unpublished paper delivered at a Conference on Debt Enforcement 16-17 March 2009 Midrand)

Van Zyl Sake Rapport

Van Zyl A 'Hulp met skuld sukkel nog' Sake Rapport 5 April 20098

Vessio 2008 SAMercLJ

Vessio ML "What does the National Credit Regulator regulate?" 2008 SA Mercantile Law Journal 227-242

Visagie 2006 De Rebus

Visagie T "Collecting your debts against the odds" 2006 De Rebus 21-23

\section{Register of legislation and government publications}

Constitution of the Republic of South Africa 1996

Gen Not 503 in Government Gazette 32229 of 15 May 2009

GN R489 in Government Gazette 28864 of 31 May 2006

Insolvency Act 24 of 1936

Magistrates' Courts Act 32 of 1944

National Credit Act 35 of 2005 


\section{Register of court cases}

Absa Bank Ltd v Myburgh Case no 31827/2007 (TPD) (unreported)

Absa Bank Ltd v Prochaska Case no 14839/2007 (D) (unreported)

Absa Bank Ltd v Whelpton Case no 35313/2008 (TPD) (unreported)

Ex parte Ford and Two Similar Cases 2009 (3) SA 376 (WCC)

First Rand Bank Ltd v Olivier [2008] JOL 22138 (SE)

First Rand Bank Ltd v Smith Case no 24205/08 (WLD) (unreported)

Frederick v Greenhouse Funding (Pty) Ltd Case no 31825/2008 (WLD)

(unreported)

Nedbank Ltd v Motaung Case no 22445/07 (TPD) (unreported)

Standard Bank of SA Ltd v Oosthuizen [2008] JOL 22036 (T)

Standard Bank of SA Ltd v Panayiotts Case no 08/00146 (WLD) (unreported)

\section{Register of internet sources}

CBM 2009 www.ncr.org.za

CBM 2009 Credit Bureau Monitor (March 2009) www.ncr.org.za [date of use 27 July 2009]

CBM 2008 www.ncr.org.za

CBM 2008 Credit Bureau Monitor (December 2008) - www.ncr.org.za [date of use 27 July 2009]

Da Silva et al 2008 www.ncr.org.za/

Da Silva M et al 2008 Debt Counselling - Principles and Guidelines www.ncr.org.za/pdfs/Guidelines/Principles\%20\&\%20Guidelines/DEBT\%20 COUNSELLING\%20\%20\%20PRINCIPLES\%20GUIDELINES\%20\%20\%20BASA\%20training\%202008.pdf [date of use 11 December 2009]

Heymans 2009 www.ncr.org.za/

Heymans M 2009 Blockages in Payment Distribution - an Investigation into the Matters that Influence the Effectiveness of Payment Distribution in the Debt Counselling System www.ncr.org.za/.../Blockages\%20Debt\%20counsellors\%2013a\%200ct\%20 \%202009.ppt 


\section{List of abbreviations}

CAA Credit Agreements Act

CBM Credit Bureau Monitor

ch chapter(s)

DCSA Debt Counselling Association of South Africa

FAIS Financial Advisory and Intermediary Services Act

MCA Magistrates' Courts Act

NCA National Credit Act

NCR National Credit Regulator

par paragraph(s)

PDA Payment Distribution Agent

reg regulation(s)

s section(s)

sch schedule(s)

SALC South African Law Commission

SALRC South African Law Reform Commission

SAQA South African Qualifications Authority 